Review

\title{
Functionalized Solid Electrodes for Electrochemical Biosensing of Purine Nucleobases and Their Analogues: A Review
}

\author{
Vimal Kumar Sharma ${ }^{1, \dagger}$, Frantisek Jelen ${ }^{2, \dagger}$ and Libuse Trnkova ${ }^{1,3, \dagger, *}$ \\ 1 Department of Chemistry, Faculty of Science, Masaryk University, Kamenice 5, CZ-625 00 Brno, \\ Czech Republic; E-Mail: vimal.shrma@gmail.com \\ 2 Institute of Biophysics of the Academy of Sciences of the Czech Republic, V.V.I., \\ Kralovopolska 135, CZ-612 65 Brno, Czech Republic; E-Mail: jelen@ibp.cz \\ 3 SIX Research Centre, University of Technology Brno, Technicka 3058/10, CZ-616 00 Brno, \\ Czech Republic
}

$\dagger$ These authors contributed equally to this work.

* Author to whom correspondence should be addressed; E-Mail: libuse@chemi.muni.cz; Tel.: +420-549-497-754; Fax: +420-549-492-443.

Academic Editor: W. Rudolf Seitz

Received: 27 November 2014 / Accepted: 4 January 2015 / Published: 14 January 2015

\begin{abstract}
Interest in electrochemical analysis of purine nucleobases and few other important purine derivatives has been growing rapidly. Over the period of the past decade, the design of electrochemical biosensors has been focused on achieving high sensitivity and efficiency. The range of existing electrochemical methods with carbon electrode displays the highest rate in the development of biosensors. Moreover, modification of electrode surfaces based on nanomaterials is frequently used due to their extraordinary conductivity and surface to volume ratio. Different strategies for modifying electrode surfaces facilitate electron transport between the electrode surface and biomolecules, including DNA, oligonucleotides and their components. This review aims to summarize recent developments in the electrochemical analysis of purine derivatives, as well as discuss different applications.
\end{abstract}

Keywords: purine derivatives; electrochemistry of purines; carbon electrode; gold electrode; platinum electrode; indium tin oxide electrode; boron doped electrode; modified electrodes 


\section{Introduction}

Based on their sensitivity, affinity and selectivity biosensors have attracted a broad research interest. Deoxyribonucleic acid (DNA) stores genetic information and is important for protein biosynthesis. Purines are the building blocks of DNA and play an important role in storing genetic information as well as contributing in cell signaling processes. Purine nucleobases (adenine, guanine) and some of their derivatives, i.e., xanthine and hypoxanthine, play an important role in biological processes [1,2]. Purines are widely involved in various diseases, most of them possess great significance in clinical and medical practice, and thus their presence and amount in biological fluids and pharmaceuticals must be carefully identified and quantified. The redox activity of the majority of purines allows their determination by means of sensitive, inexpensive and simple electrochemical sensors. The number of publications in this area is growing and interest in electrochemical analysis of purines in the last decade is documented in Figure 1.

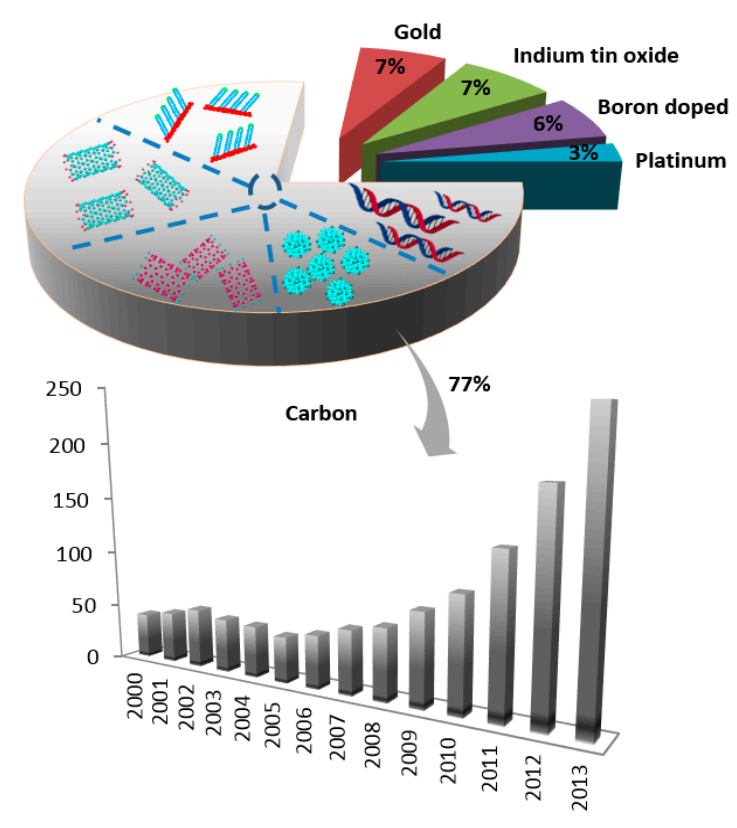

Figure 1. Papers published on electrochemistry of purine derivatives between 2004 and 2013 (from Web of Science database).

Electrochemical bioanalysis basically contains three components: the biomolecules that recognize the analytes present in the sample, the detector system which transforms the signal resulting from the interaction of these biomolecules, and finally the screen which displays the information in some user-friendly manner. Carbon-based electrodes have been used extensively for the detection of biomolecules during recent years, as shown in Figure 1.

Due to the significant role of carbon-based electrodes in biosensor fabrication, they are widely used and carbon has become a primary electrode material for improving the performance of the biosensor. Surface modifications of electrode by using nano-based materials which exhibit extraordinary electronic and physical properties provide a crucial way of influencing the performance of the biosensor. Various nanomaterials, including nanoparticles, nanotubes and graphene have achieved high versatility as electrode materials. 
Earlier studies were frequently done on mercury, mercury-film, or amalgam electrodes utilizing their reduction behavior. The analysis methods connected with the mercury electrode, even if they have advantages in some cases, are not widely used nowadays and therefore not discussed in this review. Our attempt is rather focused on oxidation of the mentioned purine derivatives on solid or solid-modified electrodes. It is known that nucleobases, as parts of DNA, RNA, nucleosides and nucleotides, are electrochemically active in the sense of electron exchange. Some of them can be reduced at negative potentials $[3,4]$, all of them can be oxidized at solid electrodes [5,6]. On the other hand, individual electrochemical investigations including structural or analytical analysis of nucleic acids are frequently based on the electrochemical behavior of their nucleobases. This review is aimed at their electrochemical analysis, which is predominantly based on their oxidation behavior on solid electrodes in water solution by sweep voltammetric methods (linear or cyclic) or pulse voltammetric methods (differential or square-wave) and/or in connection of these methods with stripping techniques or a specific electrode modification which results in more sensitive and selective determination $[4,7,8]$. Regarding the analysis of adenine and xanthine, their determinations connected with enzymatic reactions, taking place either in solution or at the electrode surface, are not included in this review. Additionally, in case of adenine, the same is also true about the determinations connected with ADP and ATP.

\section{Electrochemical Oxidation of Purine Derivatives}

\subsection{Adenine and Its Derivatives}

The adenine oxidation at carbon electrodes has been intensively studied and discussed by many authors, e.g., [9-11]. The whole process is irreversible and requires the exchange of six electrons and six protons in three subsequent steps (E1, E2, E3) involving formation of 2-hydroxyadenine (6-amino-1,3-dihydro-2H-purin-2-one) or its tautomer, then 2, 8-dihydroxyadenine (6-amino-7,9dihydro-1H-purine-2,8-dione) or its tautomer and diimine species, which can hydrolyze and give pH-dependent products [10-13].

The basic scheme is depicted in Scheme 1 [10,11]. The formation of adsorbed dimers was also observed using a carbon fiber microelectrode [14]. It was stated that the oxidation of adenine (Ade) is strongly dependent upon the electrode used and reflects both the kinetics of oxidation and the strength of bonding to the electrode surface [11]. The electrochemical oxidation of adenosine (Ado) [15] and adenosine monophosphate (AMP) [16] is more complex compared to the oxidation of Ade. Ado was found to be oxidized at more positive potentials; at $\mathrm{pH} 7$ the shift is about $300 \mathrm{mV}$ and oxygen-oxygen linked dimers are formed as a major product of oxidation at neutral medium. For AMP the oxidation proceeds in two parallel routes resulting in the formation of a variety of oxygen-oxygen and carbon-carbon linked dimers [16]. Various results dealing with the analysis of Ade and Ado depending on the type of electrode with possible modifications, methods, their detection limit and related applications are summarized in Table 1. 


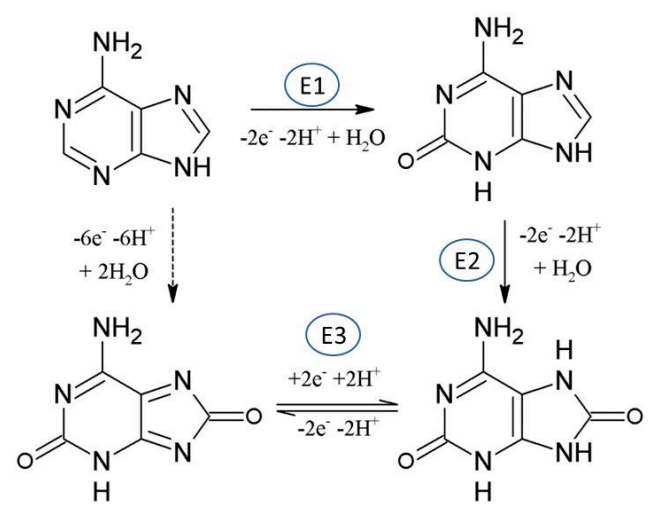

Scheme 1. Electro-oxidation of adenine.

\subsection{Guanine and Its Derivatives}

The electrochemical oxidation of guanine (Gua) was studied in aqueous media at various carbon electrodes and it was found that voltammetric behavior varied significantly depending on the type of carbon electrode [17] It was also stated that there are two dominating and controlling factors present: (a) the density of basal plane sites on which Gua can adsorb and (b) the density of edge plane sites necessary for the electrooxidation of the analytes. The oxidation mechanism of Gua is a complex one involving exchange of four electrons and four protons (E1, E2, E3). The Gua oxidation proceeds via a two electron oxidation followed by a chemical step to form 8-oxoguanine (2-amino-7,9-dihydro- $1 \mathrm{H}$ purine-6,8-dione), then 8-oxoguanine is further oxidized to form nonelectroactive products [17] (Scheme 2).<smiles>Nc1nc2[nH]c(N)nc2c(=O)[nH]1</smiles>

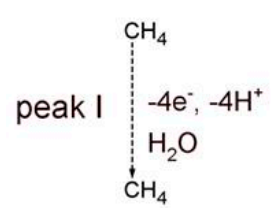

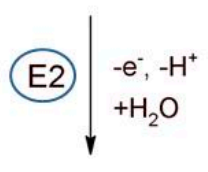

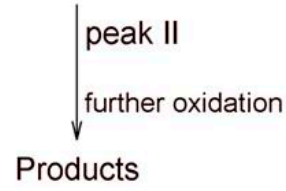<smiles></smiles>

Scheme 2. Two possible paths for the electrooxidation of guanine.

It was also proved that the electrochemical oxidation mechanism of Gua using a carbon fiber microelectrode formation of strongly adsorbed dimers is observed on the electrode surface [14]. Various studies on Gua and Guo with different modification on electrode surface are summarized in Table 2. 
Table 1. Adenine and adenosine.

\begin{tabular}{|c|c|c|c|c|c|c|}
\hline Electrode & Modification & Range of Linear Concentration Dependence & Detection Limit & Method & Application & Ref \\
\hline \multicolumn{7}{|c|}{ ADENINE } \\
\hline GCE & azocalix[4]arene film & $0.125-200.0 \mu \mathrm{M}$ & $70 \mathrm{nM}$ & $\mathrm{CV}, \mathrm{DPV}$ & detection of DNA & [18] \\
\hline BDD & no modification & 0.12 to $25 \mu \mathrm{M}$ & $19 \mathrm{nM}$ & $\mathrm{CV}, \mathrm{DPV}$ & detection of Ade in urine & [19] \\
\hline PeGE & 5-amino-2-mercapto-1,3,4,-thiazole & DNA concentration $50 \mu \mathrm{g} / \mathrm{mL}$ & - & DPV, EIS & analysis of DNA & [20] \\
\hline GCE & polymerized film of melamine & $0.1-60 \mu \mathrm{M}$ & $70 \mathrm{nM}$ & LSV, SWV & Ade determination & [21] \\
\hline $\mathrm{CPE}$ & DNA & - & $1 \mathrm{ppm}$ & $\mathrm{CV}, \mathrm{DPV}$ & interaction of flutamide with DNA & [22] \\
\hline GCE & tetraoxocalix[2]arene[2]tri azine & $0.5-10 \mu \mathrm{M}$ & $200 \mathrm{nM}$ & CV, DPV, EIS & analysis of ssDNA & [23] \\
\hline GCE & 1-phenyl-3-methyl-4-(2-furoyl)-5-pyrazolone & $0.5-100 \mu \mathrm{M}$ & $125 \mathrm{nM}$ & - & determination of Ade in pharmaceutical products & [24] \\
\hline GCE & poly(sulfosalicylic acid) and ssDNA & $65-1100 \mathrm{nM}$ & $22 \mathrm{nM}$ & $\mathrm{CV}$, DPV, EIS & analysis of nucleobases & [25] \\
\hline PyGE & no modification & - & - & $\mathrm{CV}$ & redox mechanism of Ade & [11] \\
\hline PeGE & - & - & - & DPV & DNA interaction with Pd and Pt complexes & {$[26]$} \\
\hline carbon SPE & no modification & - & - & DPV & application in DNA genotoxicity screening & [27] \\
\hline GCE & CdS-chitosan & $0.02-5 \mu \mathrm{M}$ & $40 \mathrm{nM}$ & DPV & analysis of damage DNA & [28] \\
\hline GCE & poly-(amidosulfonic acid) & $30-1000 \mathrm{nM}$ & $8 \mathrm{nM}$ & $\mathrm{CV}, \mathrm{DPV}$, EIS & analysis of vitamin B4 tablets & [29] \\
\hline GCE & cysteinic acid & $0.2-100 \mu \mathrm{M}$ & $50 \mathrm{nM}$ & DPV & analysis of vitamin B4 tablets & [30] \\
\hline SAE, PtE, AuE, GCE & - & - & - & - & construction of electrochemical multisensors & [31] \\
\hline GCE & Ade & - & $40 \mathrm{ng} / \mathrm{mL}$ & SWV & detection of antioxidant capacity in flavored water samples & [32] \\
\hline GCE, CPE, AuE & no modification & $5-30 \mathrm{ng} / \mathrm{mL}$ & - & SWV & analysis of DNA & [33] \\
\hline carbon SPE & no modification & - & - & $\mathrm{CV}, \mathrm{DPV}$ & DNA damage & [34] \\
\hline PeGE & no modification & - & - & AdSCP & detection of apurinic side in DNA & [35] \\
\hline SPE & dsDNA & - & - & DPV & interaction of antitumor drugs with dsDNA & [36] \\
\hline GCE & no modification & - & $70 \mathrm{nM}$ & DPV & determination of all bases in ssDNA & [5] \\
\hline CPE, PeGE & - & - & - & DPV & interaction of DNA with lycorine & [37] \\
\hline BDDE & no modification & $0.1-8 \mu \mathrm{g} / \mathrm{mL}$ & $3.7 \mathrm{ng} / \mathrm{mL}$ & $\mathrm{CV}, \mathrm{SWV}$ & determination of ssDNA and dsDNA & [38] \\
\hline
\end{tabular}


Table 1. Cont.

\begin{tabular}{|c|c|c|c|c|c|c|}
\hline Electrode & Modification & Range of Linear Concentration Dependence & Detection Limit & Method & Application & Ref \\
\hline \multicolumn{7}{|c|}{ ADENOSINE } \\
\hline GCE & no modification & - & - & $\mathrm{CV}, \mathrm{DPV}$ & $\begin{array}{l}\text { interaction between dsDNA and 1,2-dimyristoyl-sn- } \\
\text { glycero-3-phosphocholine }\end{array}$ & [39] \\
\hline $\mathrm{AuE}$ & thrombin aptamer & $10-1000 \mathrm{nM}$ & $10 \mathrm{nM}$ & DPV & analysis of Ado in human plasma & [40] \\
\hline $\mathrm{CPE}$ & 1-ethyl-3-methylimidazolium ethylsulfate & $1.0-270 \mu \mathrm{M}$ & $137 \mathrm{nM}$ & DPV & analysis of Ado in urine & [41] \\
\hline carbon SPE & no modification & - & - & DPV & application in DNA genotoxicity screening & [27] \\
\hline CPE, CILE & N-hexylpyridinium-hexafluorophosphate & $1.0-140 \mu \mathrm{M}$ & $0.91 \mu \mathrm{M}$ & DPV & Ado in human urine & [42] \\
\hline PeGE & no modification & - & - & AdSCP & detection of apurinic side in DNA & [35] \\
\hline GCE, PyGE & no modification & - & - & $\mathrm{CV}$ & oxidation of Ado & [15] \\
\hline
\end{tabular}

Table 2. Guanine and guanosine.

\begin{tabular}{|c|c|c|c|c|c|c|}
\hline Electrode & Modification & Range of Linear Concentration Dependence & Detection Limit & Method & Application & Ref \\
\hline \multicolumn{7}{|c|}{ GUANINE } \\
\hline GCE & azocalix[4]arene film & $2.5-650.0 \mu \mathrm{M}$ & $50 \mathrm{nM}$ & $\mathrm{CV}, \mathrm{DPV}$ & detection of DNA & [18] \\
\hline BDD & no modification & 0.21 to $23 \mu \mathrm{M}$ & $37 \mathrm{nM}$ & $\mathrm{CV}, \mathrm{DPV}$ & detection of Gua in urine & [19] \\
\hline PeGE & - & - & $2.92 \mathrm{pM}$ in $100 \mathrm{~mL}$ & DPV & $\begin{array}{l}\text { detection of hypermethylation of the glutathione } \\
\text { S-transferase P1 }\end{array}$ & [43] \\
\hline GCE & polymerized film of melamine & $0.1-50 \mu \mathrm{M}$ & $80 \mathrm{nM}$ & LSV, SWV & Gua determination & [21] \\
\hline $\mathrm{CPE}$ & DNA & - & $1 \mathrm{ppm}$ & $\mathrm{CV}, \mathrm{DPV}$ & interaction of flutamide with DNA & [22] \\
\hline GCE & tetraoxocalix[2]arene[2]tri azine & - & $80 \mathrm{nM}$ & $\mathrm{CV}, \mathrm{DPV}, \mathrm{EIS}$ & analysis of ssDNA & [23] \\
\hline GCE & poly(sulfosalicylic acid) and ssDNA & $65-1100 \mathrm{nM}$ & $22 \mathrm{nM}$ & CV, DPV, EIS & analysis of nucleobases & [25] \\
\hline PyGE, HOPG & - & - & - & $\mathrm{CV}$ & electrode reaction mechanism of Gua & [17] \\
\hline PeGE & - & - & - & DPV & DNA interaction with Pd and Pt complexes & [26] \\
\hline carbon SPE & no modification & - & - & DPV & application in DNA genotoxicity screening & [27] \\
\hline GCE & CdS-chitosan & $0.001-1.6 \mu \mathrm{M}$ & $2 \mathrm{nM}$ & DPV & analysis of damage DNA & [28] \\
\hline SAE, PtE, AuE, GCE & - & - & - & - & construction of electrochemical multisensors & [31] \\
\hline PeGE & fish sperm dsDNA & $0.018-2.56 \mathrm{ppm}$ & - & DPV & interaction of Efavirenz with fish sperm dsDNA & [44] \\
\hline
\end{tabular}


Table 2. Cont.

\begin{tabular}{|c|c|c|c|c|c|c|}
\hline Electrode & Modification & Range of Linear Concentration Dependence & Detection Limit & Method & Application & Ref \\
\hline GCE & Gua & - & $35 \mathrm{ng} / \mathrm{mL}$ & SWV & detection of antioxidant capacity in flavored water samples & [32] \\
\hline GCE, CPE, AuE & - & $5-30 \mathrm{ng} / \mathrm{mL}$ & - & SWV & analysis of DNA & [33] \\
\hline PeGE & fish sperm dsDNA & - & $0.36 \mathrm{ng} / \mathrm{mL}$ & SWV & quantification of DNA in plant extracts & [45] \\
\hline GCE & - & - & - & $\begin{array}{l}\mathrm{CV}, \mathrm{NPV} \\
\mathrm{DPV}, \mathrm{SWV}\end{array}$ & characterization of interactions of dsDNA with a drug, & [46] \\
\hline carbon SPE & no modification & - & - & $\mathrm{CV}, \mathrm{DPV}$ & DNA damage & [34] \\
\hline SPE & modification by tetraethoxysilane & $0.19-10.8 \mathrm{mg} / \mathrm{mL}$ & $0.1 \mu \mathrm{g} / \mathrm{mL}$ & $\mathrm{CV}, \mathrm{DPV}$ & electrocatalytic oxidation of Gua & [47] \\
\hline $\mathrm{AuE}$ & - & - & - & DPV & DNA analysis & [48] \\
\hline SPE & dsDNA, ssDNA & - & - & DPV, SWV & $\begin{array}{l}\text { bioanalysis of environmental pollution and } \\
\text { DNA-drug interaction }\end{array}$ & [49] \\
\hline PeGE & no modification & - & - & AdSCP & detection of apurinic side in DNA & [35] \\
\hline PeGE & - & - & - & & allele-specific DNA biosensor & [50] \\
\hline SPE & dsDNA & - & - & DPV & interaction of some antitumor drugs with dsDNA & [36] \\
\hline BDDE & - & $50 \mu \mathrm{M}$ & - & & detection of nucleosides, nucleotides and oligonucleotides & [51] \\
\hline $\mathrm{AuE}$ & - & $50 \mu \mathrm{M}$ & - & $\mathrm{CV}$ & guA oxidation at polycrystalline gold electrodes & [52] \\
\hline GCE & no modification & - & $70 \mathrm{nM}$ & DPV & determination of all bases in ssDNA & [5] \\
\hline CPE, PGE & - & - & - & DPV, PSA & interaction of arsenic trioxide with DNA & [53] \\
\hline BDDE & no modification & $0.1-8 \mathrm{mg} / \mathrm{mL}$ & $10 \mathrm{ng} / \mathrm{mL}$ & $\mathrm{CV}, \mathrm{SWV}$ & determination of ssDNA and dsDNA & [38] \\
\hline $\mathrm{AuE}$ & L-cysteine monolayer & $2.5-15 \mathrm{pmol}$ & - & SWV & DNA hybridization & [54] \\
\hline CPE, PeGE & - & - & - & DPV & interaction of DNA with lycorine & [37] \\
\hline \multicolumn{7}{|c|}{ GUANOSINE } \\
\hline GCE & no modification & - & - & $\mathrm{CV}, \mathrm{DPV}$ & $\begin{array}{l}\text { interaction between dsDNA and 1,2-dimyristoyl-sn-glycero- } \\
\text { 3-phosphocholine }\end{array}$ & [39] \\
\hline $\mathrm{CPE}$ & $\begin{array}{l}\text { 1-ethyl-3-methylimidazolium } \\
\text { ethylsulfate }\end{array}$ & $1.0-160 \mu \mathrm{M}$ & $183 \mathrm{nM}$ & DPV & analysis of Guo in urine & [41] \\
\hline GCE & no modification & $0.5 \mu \mathrm{M}-1.0 \mathrm{mM}$ & $145 \mathrm{nM}$ & DPV & Guo in human blood plasma and urine & [55] \\
\hline BDDE & - & $100 \mu \mathrm{M}$ & - & - & detection of nucleosides, nucleotides and oligonucleotides & [51] \\
\hline
\end{tabular}




\section{Xanthine and Its Derivatives}

The mechanism of xanthine (Xan) oxidation was suggested earlier by several electrochemists [9,56,57], revised and discussed later [58]. The whole process proceeds in two steps (E1, E2); in the first step oxidation to uric acid (7,9-dihydro-1H-purine-2,6,8(3H)-trione) takes place, which is immediately oxidized to diimine, which is hydrolyzed and gives $\mathrm{pH}$-dependent products, similarly as in the case of Ade. Therefore, the voltammetric signal corresponds to the overall requirement of four electrons and four protons (Scheme 3). The results published on Xan and its derivatives are summarized in Table 3.

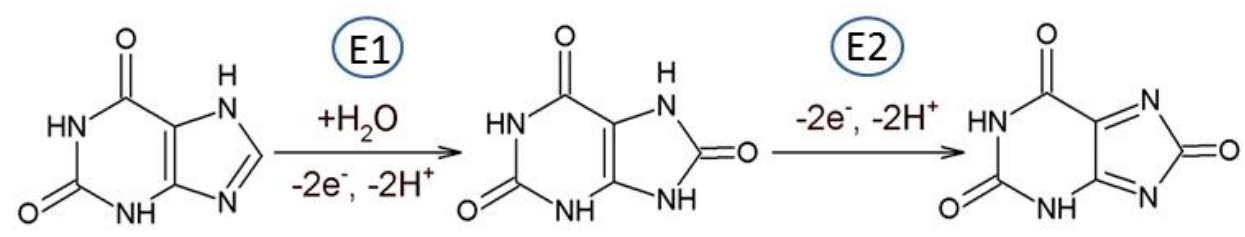

Scheme 3. Electrooxidation of xanthine.

\section{Nucleobase Assemblies on Solid Electrode}

\subsection{Bare Electrode}

In 2004, an important paper was published [5], where bare GCE was used for simultaneous determination of all nucleobases in combination with the DPV method. The GCE was not modified, only electrochemical preconditioning including washing, sonication and anodic polarization was done. It was concluded that detection limits in the nano- and micromolar range were obtained for purine and pyrimidine bases and that the results presented show for the first time that the pyrimidine nucleosides and nucleotides are electroactive on GCE and that, in addition to the easy detection of purines, it was also possible to detect simultaneously the oxidation of pyrimidine residues in ssDNA [5]. Bare GCE was also used for the formation of a dsDNA-liposome complex by the decrease of the dsDNA oxidation peaks, dependent upon the incubation time. This behavior was explained considering the electroactive centers of dsDNA, GMP and AMP residues, part of them hidden inside the dsDNA-liposome complex structure and thus unable to reach the GC electrode and preventing their oxidation [39]. Carbon SPE has been investigated as a possible sensor to identify $\gamma$-irradiation induced oxidative damage in dsDNA by CV and DPV [34]. The same electrodes were used for a simple differential pulse voltammetric genotoxicity assay utilizing dsDNA in free solution based on the DNA damage by potassium dichromate [27]. Also other types of unmodified electrodes like the pyrolytic graphite electrode (PyGE) and pencil graphite electrode (PeGE) were used for electrochemical monitoring of nucleobases or DNA. DPV by using renewable PeGE was employed to monitor the DNA interaction of Pd(II) and $\mathrm{Pt}$ (II) metal complexes with fish sperm dsDNA based on the oxidation signals of Gua and Ade at the surface or in solution [26]. 
Table 3. Xanthine and hypoxanthine.

\begin{tabular}{|c|c|c|c|c|c|c|}
\hline Electrode & Modification & $\begin{array}{c}\text { Range of Linear Concentration } \\
\text { Dependence } \\
\end{array}$ & $\begin{array}{c}\text { Detection } \\
\text { Limit }\end{array}$ & Method & Application & Ref \\
\hline \multicolumn{7}{|c|}{ XANTHINE } \\
\hline GCE & poly L-methionine & - & $4 \mathrm{nM}$ & $\mathrm{CV}, \mathrm{DPV}$ & detection of xanthine in serum & [59] \\
\hline GCE & poly(xylitol) & $1.3-75.3 \mu \mathrm{M}$ & $0.75 \mu \mathrm{M}$ & $\mathrm{CV}$ & determination in urine & [60] \\
\hline $\mathrm{AuE}$ & xanthine oxidase & $2-16 \mu \mathrm{M}$ & $0.15 \mu \mathrm{M}$ & - & xanthine in fish, chicken, pork, and beef meat & [61] \\
\hline GCE & graphitized mesoporous carbon & $20-320 \mu \mathrm{M}$ & $388 \mathrm{nM}$ & - & human blood-plasma, urine and fish samples & [62] \\
\hline PtE & polyvinylchloride & $25-400 \mathrm{nM}$ & $25 \mathrm{nM}$ & - & xanthine in fish meat, cow and buffalo milk & [63] \\
\hline GCE & $\begin{array}{c}\text { 3-aminopropyltriethoxysilane/glutaraldehyde/xanthine } \\
\text { oxidase/chitosan }\end{array}$ & $0.5-18 \mu \mathrm{M}$ & $21.5 \mathrm{nM}$ & - & $\begin{array}{l}\text { construction of biosensors, } \\
\text { determination of xanthine }\end{array}$ & [64] \\
\hline GCE & mesoporous carbon & $20-200 \mu \mathrm{M}$ & $46 \mathrm{nM}$ & $\mathrm{CV}, \mathrm{DPV}$ & determination of xanthine & [65] \\
\hline GCE & polymerized film of bromocresol purple & $0.1-100 \mu \mathrm{M}$ & $60 \mathrm{nM}$ & DPV & simultaneous determination in human serum & [66] \\
\hline GCE & acetylene black and dihexadecyl hydrogen phosphate & three orders of magnitude & $60 \mathrm{nM}$ & $\mathrm{CV}$ & rat striatal microdialysates of freely moving rats & [67] \\
\hline \multicolumn{7}{|c|}{ HYPOXANTHINE } \\
\hline GCE & poly L-methionine & - & $8 \mathrm{nM}$ & $\mathrm{CV}, \mathrm{DPV}$ & detection of hypoxanthine in serum & [59] \\
\hline GCE & poly(xylitol) & $5-55 \mu \mathrm{M}$ & $4.5 \mu \mathrm{M}$ & $\mathrm{CV}$ & determination in urine & [60] \\
\hline GCE & graphitized mesoporous carbon & $20-240 \mu \mathrm{M}$ & $351 \mathrm{nM}$ & DPV & human blood-plasma, urine and fish samples & [62] \\
\hline GCE & 3-amino-5-mercapto-1,2,4-triazole & - & - & DPV & $\begin{array}{l}\text { hypoxanthine in human blood serum } \\
\text { and urine samples }\end{array}$ & [68] \\
\hline GCE & mesoporous carbon & $20-150 \mu \mathrm{M}$ & $69 \mathrm{nM}$ & $\mathrm{CV}, \mathrm{DPV}$ & determination of hypoxanthine & [65] \\
\hline GCE & polymerized film of bromocresol purple & $0.2-80 \mu \mathrm{M}$ & $120 \mathrm{nM}$ & DPV & simultaneous determination in human serum & [66] \\
\hline GCE & acetylene black and dihexadecyl hydrogen phosphate & three orders of magnitude & $250 \mathrm{nM}$ & $\mathrm{CV}$ & rat striatal microdialysates of freely moving rats & [67] \\
\hline \multicolumn{7}{|c|}{ INOSINE } \\
\hline GCE & 3-amino-5-mercapto-1,2,4-triazole & - & $50 \mathrm{nM}$ & DPV & Inosine in human blood serum and urine samples & [68] \\
\hline
\end{tabular}


A simple and rapid approach for detecting apurinic sites in DNA, based on direct stripping chronopotentiometric measurements of Ade and Gua nucleobases at a PeGE was described [35]. Experiments with mixtures of free nucleobases and purine nucleosides revealed that the larger $\mathrm{A} / \mathrm{G}$ ratio observed in the electrochemical analysis of apurinic site-containing oligomers is attributed to the influence of the acid and/or thermal decomposition products. This study represented the first step in developing a simple and direct electrochemical assay of apurinic sites in ssDNA. PyGE represents a good tool for the study of electrochemical oxidation of Ado in a wide range of $\mathrm{pH}$ [15] and the electrochemical oxidation mechanism of Ade which included a reflection of both the kinetics of oxidation and the strength of bonding to the electrode surface, both of which are surface specific [11].

\subsection{Boron-Doped Diamond Electrodes}

Boron-doped diamond (BDD) electrodes are attractive for electrochemical analysis due to their advantages, i.e., a large potential window in aqueous solution, a low background current, and a high electrochemical stability. BDD electrodes have been used for the electrochemical oxidation of underivatized-nucleic acids in terms of single stranded and double stranded DNA in connection with cyclic voltammetry and square wave voltammetry [38]. At the BDD electrode, at least two well-defined voltammetric peaks were observed for both single stranded and double stranded DNA. BDD electrode is the first material to show a well-defined voltammetric peak for Ade group oxidation directly in the helix structure of nucleic acid due to its wide potential window. For single stranded DNA, a third peak was observed, related to the pyrimidine group oxidation. Linear calibration results have shown linearity of current with concentrations in the range of $0.1-8 \mu \mathrm{g} / \mathrm{mL}$ for both Gua and Ade residues at as-deposited BDD. Detection limits $(\mathrm{S} / \mathrm{N}=3)$ of 3.7 and $10 \mathrm{ng} / \mathrm{mL}$ for Ade and Gua residue in single stranded DNA, respectively, and 5.2 and $10 \mathrm{ng} / \mathrm{mL}$ for Ade and Gua residue in double stranded DNA, respectively, were observed [38].

BDD electrodes are frequently used in chromatographic or electrophoretic detectors due to their high stability for analysis of biological samples. In the case of simultaneous detection of purine and pyrimidine bases in mild acidic media by using HPLC with amperometric detection no deactivation of the electrode was found during cyclic voltammetric and HPLC measurements [69]. Similarly, a good stability and reproducibility reflecting the minimal adsorption of purines at the BDD surface at microchip capillary electrophoresis coupled with a BDD electrode was observed for the separation and detection of several purines and purine-containing compounds [51]. Quite recently, a BDD electrode was proposed as a simple electrochemical sensor for sensitive determination of Ade and Gua in native, thermally and acid denatured DNA samples from fish sperm and acid denatured DNA samples from human placenta [19]. A boron-doped carbon nanotubes modified glassy carbon electrode was predicted to provide a potential application for the electrochemical detection of DNA in the field of genetic-disease diagnosis [70]. This prediction was made on the excellent results in which the remarkable electrocatalytic activity towards the oxidation of purine bases and direct oxidation of pyrimidine bases was followed at this modified electrode.

A BDD electrode was also used for hydrolyzed oligodeoxynucleotides and DNA, and a report on copper-enhanced label-free anodic stripping detection of Ade and Gua bases in acid-hydrolyzed DNA was published [71]. The analysis was performed in a small volume $(50 \mu \mathrm{L})$ and efficient stirring 
during the accumulation step by streaming of an inert gas was used. The accelerated mass transport due to the solution motion resulted in an enhancement of the guanine oxidation signal by about two orders of magnitude (compared to accumulation of the analyte from a solution not containing copper), allowing an easy detection of $\sim 25 \mathrm{fmol}$ of the ODNs [71]. The proposed technique was shown to be suitable for the determination of purine (particularly guanine) content in DNA samples.

\subsection{Indium-Tin Oxide (ITO) Electrodes}

Indium tin oxide (tin-doped indium oxide) is a solid solution of indium(III) oxide $\left(\mathrm{In}_{2} \mathrm{O}_{3}\right)$ and tin(IV) oxide $\left(\mathrm{SnO}_{2}\right)$, typically 9:1 by weight, which is optically transparent, electrically conductive, colorless in thin layers, and can be used as a working electrode in electrochemical experiments, e.g., [72]. Its special properties made it a suitable and significant tool for systems dealing with detection of DNA hybridization by electrocatalytic oxidation of Gua [73-75] in the presence of ruthenium tris (2,2'-bipyridine) cation used as a redox mediator for the catalytic reaction [76-79]. ITO surface frequently serves as a substrate for additional modification by different substances, e.g., gold nanoparticles [80], chitosan in combination of MWCNT [81] or graphene [82], titanium dioxide [83], etc. An ITO electrode modified by nanogold was used for the simultaneous determination of ADO and ATP with detection limits as $0.07 \mathrm{mM}$ and $0.10 \mathrm{mM}$, respectively [80]. On the other hand, a composite film, which contains MWCNT along with the incorporation of poly(neofuchsin) [84], has been synthesized also on ITO electrode by potentiostatic methods. This composite electrode was used for the simultaneous determination of Gua and Ade [84] with satisfactory results.

\section{Surface Modification Approaches to Enhance Electrochemical Activity of Purines}

\subsection{Nanostructured Materials}

Nanostructured materials have received widespread considerable attention due to their extraordinary physical and chemical properties. In recent years nanomaterials with tailored morphological features and exclusive potential properties have provoked an immense interest in the range of fields including electrochemical biosensing. Electrochemical sensing significantly exploited nano-based materials as functional electrode materials in order to achieve a simple and inexpensive analytical method for the detection of biomolecules. To understand the electrochemical behavior nanomaterials including graphene, carbon nanotubes (CNTs) and nanoparticles (NPs) have been discussed in this section. Some papers demonstrate an enhanced electrochemical signal on pencil electrode that can be achieved by various nano-based modifications. The unique properties of nano-based materials accelerate electron transfer and enhance the electrochemical activity of biomolecules.

\subsubsection{Graphene}

Carbon materials have been widely used in electrochemical sensing because of their promising properties, including a wide potential range compared to other solid electrodes, low cost, low background and chemical inertness for biosensing in various electrolyte solutions [85,86]. In 2004 Novoselov et al. [87,88] observed that carbon sheets of a thickness of up to few atomic layers possessed electric field effects. These two dimensional (2D) sheets of $\mathrm{sp}^{2}$ bonded carbon possess 
uncommon electronic and electrochemical properties [89-91] making it a promising candidate for electrochemical applications. There has been a significant increase in the use of graphene for electrochemical application in past years. It has been demonstrated that graphene can exhibit potential advantages including electrochemical activity, surface area compared to the other carbon materials including CNTs [92-94] or glassy carbon [95].

As shown in Figure 2, the graphene based electrode enhanced two to four times oxidation of signals compared to CNTS based electrode. The 2D sheet of aromatic ring is not infinite and differs according to its basal and edge planes [96]. However, the edge plane of graphene sheets exhibits electrochemically active sites, whereas the basal plane is considered to be electrochemically inert [90]. Subsequently, significant contributions have been made on graphene-based electroanalysis of oxidations of purines [97-101]. Zhu et al. [102] demonstrated graphene-based electrochemical determination of Ade and Gua on a modified glassy carbon electrode which not only exhibits excellent electrochemical activity for Ade and Gua bases, but also shows high selectivity, reproducibility and stability. The detection limits (based on $\mathrm{S} / \mathrm{N}$ of 3) for Ade and Gua are $0.1 \mu \mathrm{M}$ and $0.2 \mu \mathrm{M}$, which are more sensitive than a graphene/Nafion composite film modified glassy carbon electrode where the detection limits of Ade and Gua were determined to be $0.75 \mu \mathrm{M}$ and $0.58 \mu \mathrm{M}$, respectively [100]. The enhanced electrochemical activity contributed to the exclusive properties of graphene including large surface area, electronic properties [103].

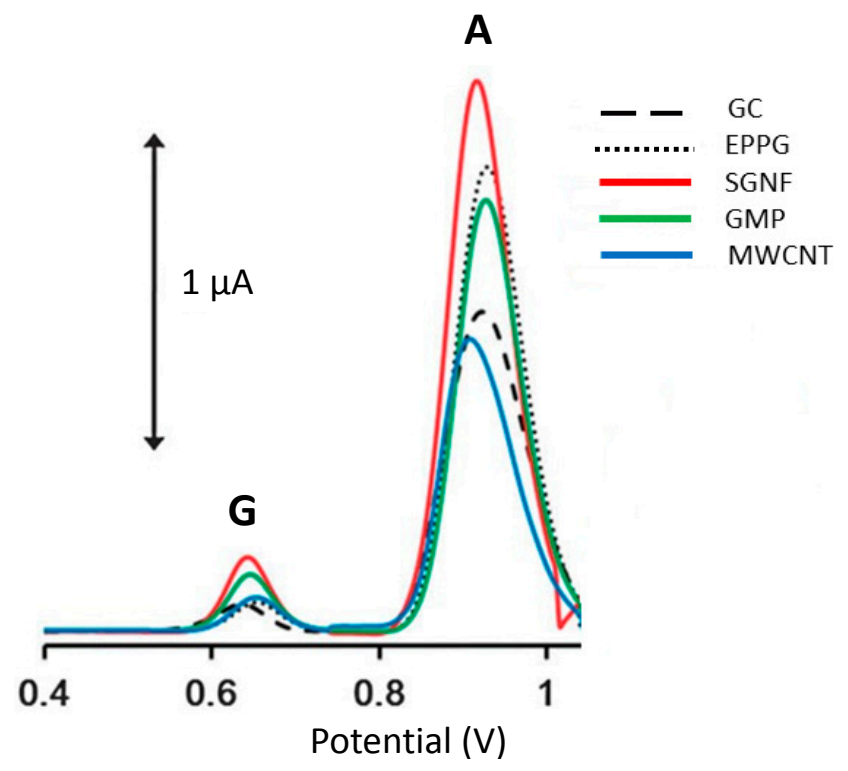

Figure 2. DPV of Gua (G) and Ade (A) on glassy carbon (GC), edge plane pyrolytic

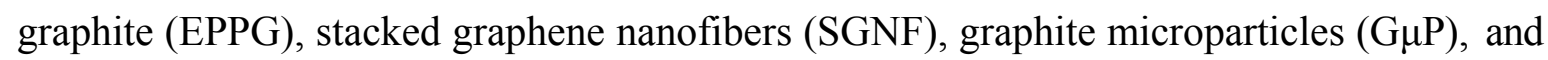
MWCNT electrodes for electrochemical detection. Reproduced from [93] with permission.

More recently, Liu et al. [104] demonstrated that the polymer/graphene composite displayed excellent electrocatalytic activities for the determination of Ade and Gua nucleobases. Furthermore, Wang et al. [105] showed that increased porosity and acidic groups on the graphene surface enhanced the electrochemical detection of purines. The enhanced performance features of graphene, modified graphene, may be the result of increased edge plane defective sites, which enhances the electron transport [106]. 


\subsubsection{Carbon Nanotubes}

Carbon nanotubes (CNTs) have been extensively exploited in the area of electrochemical bio-sensing [107,108]. Since the discovery of CNTs by Iijima in 1991 [109], their exceptional electrochemical properties have captivated bioanalysts to use them as electrode materials for electrochemical analysis [110,111]. CNTs comprise single or multiple layers of needle-like cylindrical hollow structures of carbon having high aspect ratios [109]. A schematic view of single-walled carbon nanotube (SWCNT) or multi-walled carbon nanotube (MWCNT) can be seen in Figure 3.

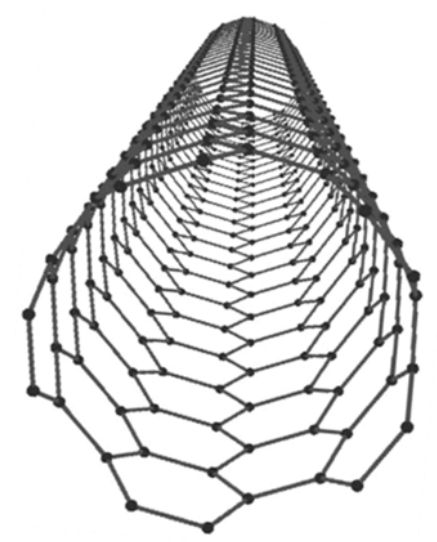

A

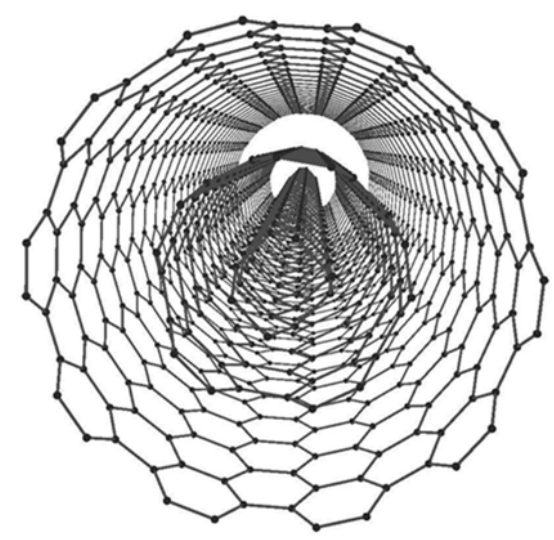

B

Figure 3. Schematic representation of (A) single-walled carbon nanotubes (SWCNT) and (B) multi-walled carbon nanotubes (MWCNT).

SWCNTs are nanometer diameter wrapped sheets of $\mathrm{sp}^{2}$ bonded graphene [112], whereas MWCNTs are multiple rolled assemblies of SWCNT [113]. Extensive excellent reviews discuss the potential application of CNTs in the area of electrochemical detection of biomolecules due to their active participation in accelerating electron transfer [110,111,114-119]. During the last decade significant efforts have been made in using CNT-based electrochemical biosensing. The simplest strategy to fabricate CNT modified electrodes is the treatment of the electrode by a dispersion of CNT followed by evaporation of the solvent. CNT modified electrodes are highly sensitive and suitable to detect nucleobases [120]. Wu et al. demonstrated in 2003 [121] the dramatically enhanced response of Gua and Ade on CNT-modified GCE compared to the bare GCE surface. CNT allows a significant adsorption of nucleobases and apparently enhances the oxidation signals [121]. Recent studies have also demonstrated involvement of CNT to enhance the oxidation signals for electrochemical detection of nucleobases [122,123]. Goyal et al. [124] demonstrated an inexpensive and efficient tool for oxidative DNA damage detection. They observed enhanced oxidation signals of 8-hydroxyGua and Gua on a single-walled carbon nanotube (SWCNT) modified edge plane PyGE compared to the bare edge plane PyGE as shown in Figure 4. The observed limits of detection were $0.05 \times 10^{-9}$ and $0.01 \times 10^{-9} \mathrm{~mol} / \mathrm{L}$, respectively [124]. 


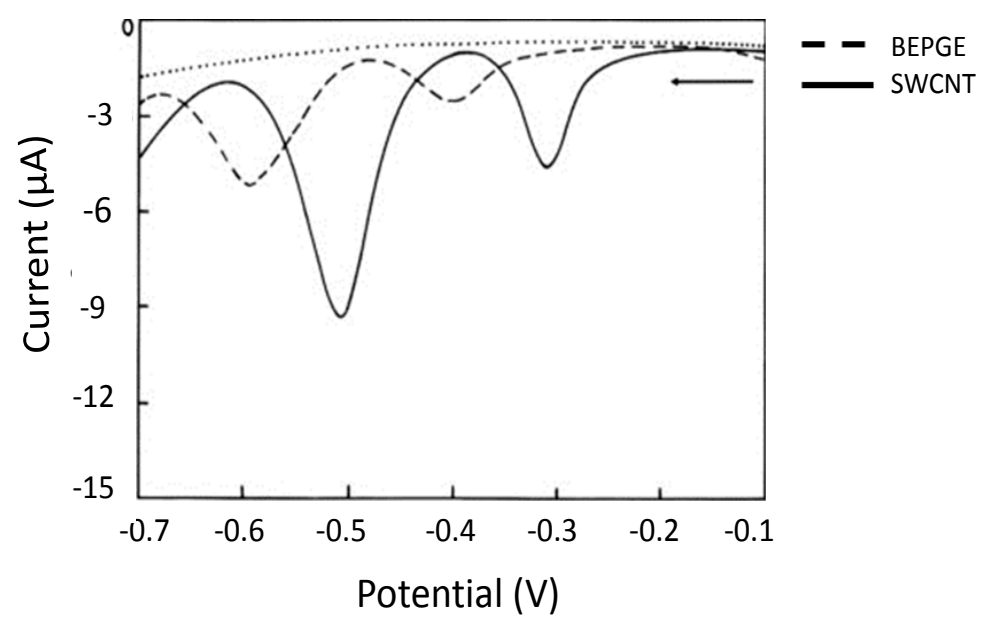

Figure 4. SWV of Gua and 8-hydroxyGua at (a) bare edge plane pyrolytic graphite electrode (BEPGE) and (b) SWCNT modified EPPGE; the dotted line is SWV of blank PBS using SWCNT/EPPGE at pH 7.2. Reproduced from [124] with permission.

Furthermore, in another study they determined 2, 8-dihydroxyadenine (2,8-DHA) in order to monitor DNA damage by using an SMNT-modified edge plane pyrolytic graphite electrode. An enhanced electrochemical response with a limit of detection of Ade is $0.038 \mathrm{nM}$ [125]. The extraordinary capability of CNT towards oxidation signals acts as an enhancer to invoke electrochemical detection of Gua and 8-hydroxyGua (Figure 4). It was demonstrated by Goyal and Bishnoi [125]. For reasons of clarity the determination of purine derivatives at various modified electrodes is summarized in Table 4.

\subsubsection{Nanoparticles}

Nanomaterials have attracted considerable attention during the last decade in various kinds of analytical methods because of their intriguing physicochemical properties different from those of bulk materials. Particles referred to as nanoparticles (NPs), usually in the range between 1 and $100 \mathrm{~nm}$, which exhibit a high surface-to-volume ratio, are potential tools for various applications in biosensing [126-128]. A vast variety of metallic [129,130] and polymeric NPs [131] have been used for electrochemical biosensing. In addition, NPs of noble metals, including gold (Au) NPs, possess potential applications in the field of biosensing due to their attractive physicochemical and catalytic properties [132,133]. Detailed information can be found elsewhere [134]. NPs play a significant role in amplifying the electrochemical response. Because of their high surface energy, NPs become unstable and aggregate, and thus it is difficult to attain monodispersity. To overcome this situation NPs are capped by any suitable stabilizing agent in order to improve the stability and performance [135]. However, due to the high energy and high surface area, NPs bind to biomolecules strongly and allow them to immobilize on the surface by electrostatic or covalent interaction for various biosensor applications $[129,136]$. Gold NPs have been used more frequently because of biocompatibility and stability; also other NPs were used including $\mathrm{Ag}, \mathrm{TiO}_{2} \mathrm{Pt}$, etc. Oxidation of DNA bases highlights the first straightforward detection of DNA damage. Goyal et al. [137] used a gold NPs-modified electrode for the voltammetric determination of Guo in neutral medium. They observed an effective catalytic response towards its oxidation and estimation in the human plasma samples with good reproducibility. 
Table 4. Determination of purine derivatives on modified electrodes.

\begin{tabular}{|c|c|c|c|c|c|c|}
\hline Electrode & Modification & $\begin{array}{c}\text { Range of Linear } \\
\text { Concentration Dependence }\end{array}$ & $\begin{array}{c}\text { Detection } \\
\text { Limit }\end{array}$ & Method & Application & Ref \\
\hline \multicolumn{7}{|c|}{ ADENINE } \\
\hline ITO & gold nanodots & $0.25-90 \mu \mathrm{M}$ & $500 \mathrm{nM}$ & $\mathrm{CV}, \mathrm{DPV}$ & Ade determination in human serum & [138] \\
\hline GCE & Ag-PMel & $0.1-60 \mu \mathrm{M}$ & $8 \mathrm{nM}$ & CV, SWV, LSV & detection of Ade & [139] \\
\hline GCE & chitosan carbon nanofibers & $0.2-50 \mu \mathrm{M}$ & $73.8 \mathrm{nM}$ & $\mathrm{CV}$ & detection of beef kidney sample & [140] \\
\hline $\mathrm{Pt}$ & MWCNT & - & $3 \mu \mathrm{M}$ & LSV & detection of Ade & [141] \\
\hline $\mathrm{Pt}$ & Au NPs/graphene & - & - & LSV & detection of Ade & [142] \\
\hline GCE & Au nps & - & $4 \mathrm{nM}$ & CV, DPV & detection of Ade & [143] \\
\hline CPE & $\mathrm{TiO}_{2}-\mathrm{NPs}-\mathrm{MgY} / \mathrm{Zm}$ & - & $0.02 \mu \mathrm{M}$ & $\mathrm{CV}, \mathrm{DPV}$ & detection of Ade & [144] \\
\hline GCE & graphite nanopowder and MWCNT & - & - & DPV & detection of Ade in meat & [145] \\
\hline GCE & reduced graphene oxide & - & $200 \mathrm{nM}$ & - & detection of Ade in ssDNA & [102] \\
\hline GCE & reduced graphene & $20 \mu \mathrm{M}$ oligonucleotides & - & DPV & analysis of DNA & [146] \\
\hline GCE & reduced graphene oxide & units to hundreds $\mathrm{mM}$ & - & DPV & detection of DNA & [147] \\
\hline GCE & multi-layer of graphene & units to tens of $\mathrm{mM}$ & - & - & construction of genosensors & [148] \\
\hline GCE & boron-doped carbon nanotubes & - & - & DPV & detection of DNA in the field of genetic-disease diagnosis & {$[70]$} \\
\hline SPE & $\beta$-cyclodextrin/poly(N-acetylaniline)/CNT & $10-1020 \mu \mathrm{M}$ & $50 \mathrm{nM}$ & - & sensor of DNA hybridization & [149] \\
\hline GCE & MWCNT/choline & - & - & - & simultaneous detection of DNA & [122] \\
\hline GCE & ssDNA and AuNP & - & - & $\mathrm{CV}, \mathrm{DPV}$ & inhibition effect of Ade & [150] \\
\hline GCE & $\mathrm{PbO}_{2} / \mathrm{CNT} / 1$-butyl-3-methylimidazolium hexafluorophosphate & - & $30 \mathrm{nM}$ & - & analysis of herring sperm DNA & [151] \\
\hline GCE & different chemically-modified graphene & - & - & DPV & device for label-free DNA analysis & [152] \\
\hline GCE & $\mathrm{TiO}_{2}$-graphene nanocomposite & $0.5-200 \mu \mathrm{M}$ & $0.1 \mu \mathrm{M}$ & $\mathrm{CV}, \mathrm{DPV}$ & electrochemical sensor of Ade & [99] \\
\hline PyGE & SWCNT & $5-100 \mathrm{nM}$ & $3.7 \mathrm{nM}$ & SWV & Ade in human urine & [153] \\
\hline GCE & $\mathrm{TiO}_{2}$ nanobelts & - & - & $\mathrm{CV}, \mathrm{DPV}$ & analysis of DNA & [154] \\
\hline GCE & MWCNT & - & $80 \mathrm{nM}$ & $\mathrm{LSV}, \mathrm{CV}$ & analysis of DNA & [155] \\
\hline GCE & CdS-chitosan & - & nM range & DPV & analysis of DNA damage & {$[28]$} \\
\hline graphene NF & CNT & - & - & - & analysis of DNA & [93] \\
\hline GCE & DNA/MWCNT & - & - & $\mathrm{CV}, \mathrm{DPV}, \mathrm{SWV}$ & monitoring of phenolic pollutants & [156] \\
\hline GCE, AuE, ITO & MWCNT/poly(new fuchsin) & - & - & $\mathrm{CV}, \mathrm{DPV}$ & & [84] \\
\hline GCE & $\beta$-cyclodextrin/MWCNT & - & $0.75 \mathrm{nM}$ & DPV & & [157] \\
\hline
\end{tabular}


Table 4. Cont

\begin{tabular}{|c|c|c|c|c|c|c|}
\hline Electrode & Modification & $\begin{array}{c}\text { Range of Linear } \\
\text { Concentration Dependence }\end{array}$ & $\begin{array}{c}\text { Detection } \\
\text { Limit }\end{array}$ & Method & Application & Ref \\
\hline GCE & MWCNT, AuNP & $0.008-2.0 \mu \mathrm{M}$ & $5 \mathrm{nM}$ & $\mathrm{CV}$, & analysis of milk, plasma and urine & [158] \\
\hline GCE & Ade & - & $40 \mathrm{ng} / \mathrm{mL}$ & SWV & detection of antioxidant capacity in flavored water samples & [32] \\
\hline GCE & $\mathrm{CNTs} / \mathrm{La}(\mathrm{OH})_{3}$ & - & $220 \mathrm{nM}$ & $\mathrm{CV}, \mathrm{DPV}$ & analysis of DNA & [159] \\
\hline GCE, CPE, AuE & - & $5-30 \mathrm{ng} / \mathrm{mL}$ & - & SWV & analysis of DNA & [33] \\
\hline GCE, AuE, TOE & MWCNT, AuNP, hydroxypropyl- $\beta$-cyclodextrin & - & - & $\mathrm{CV}, \mathrm{DPV}$ & electrochemical characterizations and surface morphology studies & [160] \\
\hline GCE & SWCNT/poly(acridine orange) & - & $1.8 \mathrm{nM}$ & $\mathrm{CV}, \mathrm{DPV}$ & simultaneous determination of Ade in DNA & [161] \\
\hline PyGE & $\beta$-cyclodextrin/CNT & - & $0.2 \mathrm{mg} / \mathrm{mL}$ & DPV & simultaneous or individual determination of Ade & {$[120]$} \\
\hline SPE & MWCNT & - & - & $\mathrm{CV}$ & detection DNA and RNA & {$[162]$} \\
\hline GCE & SWCNT & - & - & $\mathrm{CV}, \mathrm{DPV}$ & analysis of DNA & [163] \\
\hline GCE & SWCNT & - & - & $\mathrm{CV}, \mathrm{DPV}$ & analysis of DNA & [164] \\
\hline \multicolumn{7}{|c|}{ ADENOSINE } \\
\hline PyGE & SWCNT & $10-100 \mathrm{nM}$ & $7.6 \mathrm{nM}$ & SWV & Ado in human urine & [153] \\
\hline GCE & fullerene $\mathrm{C}_{60}$ & $0.01-100 \mu \mathrm{M}$ & $80 \mathrm{nM}$ & & Ado in urine & [12] \\
\hline GCE & fullerene $\mathrm{C}_{60}$ & $0.5-1000 \mu \mathrm{M}$ & $302 \mathrm{nM}$ & DPV & Ado in urine and blood plasma & [165] \\
\hline GCE & fullerene $\mathrm{C}_{60}$ & $0.5 \mu \mathrm{M}-1.0 \mathrm{mM}$ & $302 \mathrm{nM}$ & DPV & Ado in human blood plasma and urine & [55] \\
\hline \multicolumn{7}{|c|}{ GUANINE } \\
\hline ITO & gold nanodots & - & $250 \mathrm{nM}$ & DPV & Ade determination in human serum & [138] \\
\hline GCE & Ag-PMel & $0.1-50 \mu \mathrm{M}$ & $8 \mathrm{nM}$ & $\mathrm{CV}, \mathrm{SWV}, \mathrm{LSV}$ & detection of Gua & [139] \\
\hline GCE & chitosan carbon nanofibers & $0.2-50 \mu \mathrm{M}$ & $46.8 \mathrm{nM}$ & $\mathrm{CV}$ & detection of beef kidney sample & {$[140]$} \\
\hline GCE & graphene oxide & - & - & $\mathrm{CV}, \mathrm{DPV}$ & determination of Gua & {$[166]$} \\
\hline GCE & Au NPS & - & $5 \mathrm{nM}$ & $\mathrm{CV}, \mathrm{DPV}$ & detection of Gua & [143] \\
\hline $\mathrm{CPE}$ & $\mathrm{TiO}_{2}$ nps-MgY/Zm & - & $0.013 \mu \mathrm{m}$ & $\mathrm{CV}, \mathrm{DPV}$ & detection of gua & [144] \\
\hline GCE & MWCNT/ionic liquid/chitosan & $0.5-30 \mathrm{nM}$ & $37 \mathrm{pM}$ & DPV & detection of human immunoglobulin $\mathrm{E}$ & [167] \\
\hline PeGE & - & - & $\begin{array}{c}2.92 \mathrm{pM} \text { in } \\
100 \mathrm{~mL} \\
\end{array}$ & DPV & detection of hypermethylation of the glutathione S-transferase P1 & [43] \\
\hline $\mathrm{CPE}$ & nanostructured Pt thin film & $0.1-500 \mu \mathrm{M}$ & $31 \mathrm{nM}$ & DPV & determination of Gua & [168] \\
\hline GCE & reduced graphene & $20 \mu \mathrm{M}$ oligonucleotides & - & DPV & analysis of DNA & [146] \\
\hline GCE & reduced graphene oxide & - & $150 \mathrm{nM}$ & - & detection of Gua in ssDNA & {$[102]$} \\
\hline
\end{tabular}


Table 4. Cont

\begin{tabular}{|c|c|c|c|c|c|c|}
\hline Electrode & Modification & $\begin{array}{c}\text { Range of Linear } \\
\text { Concentration Dependence }\end{array}$ & $\begin{array}{c}\text { Detection } \\
\text { Limit }\end{array}$ & Method & Application & Ref \\
\hline GCE & boron-doped carbon nanotubes & - & - & DPV & detection of DNA in the field of genetic-disease diagnosis & [70] \\
\hline SPE & $\beta$-cyclodextrin/poly(N-acetylaniline)/CNT & $10-1020 \mu \mathrm{M}$ & $50 \mathrm{nM}$ & - & sensor of DNA hybridization & [149] \\
\hline GCE & reduced graphene oxide & units to hundreds $\mathrm{mM}$ & - & DPV & detection of DNA & [147] \\
\hline GCE & multi-layer of graphene & units to tens of $\mathrm{mM}$ & - & - & construction of genosensors & [148] \\
\hline PeGE & polymer-ZnO nanoparticle & - & & DPV, EIS & sequence-selective DNA hybridization & [169] \\
\hline GCE & MWCNT/choline & - & - & - & simultaneous detection of DNA & [122] \\
\hline GCE & $\mathrm{PbO}_{2} / \mathrm{CNT} / 1$-butyl-3-methylimidazolium hexafluorophosphate & - & $6 \mathrm{nM}$ & - & analysis of herring sperm DNA & [151] \\
\hline GCE & worm-like cobalt oxide nanostructures & $40 \mathrm{nM}-10 \mu \mathrm{M}$ & $3 \mathrm{nM}$ & $\mathrm{CV}$ & determination of Gua & [170] \\
\hline GCE & different chemically-modified graphene & - & - & DPV & device for label-free DNA analysis & [152] \\
\hline GCE & poly(sulfosalicylic acid) and ssDNA & $65-1100 \mathrm{nM}$ & $22 \mathrm{nM}$ & EIS & analysis of nucleobases & [25] \\
\hline GCE & $\mathrm{TiO}_{2}$-graphene nanocomposite & $0.5-200 \mu \mathrm{M}$ & $0.15 \mu \mathrm{M}$ & $\mathrm{CV}, \mathrm{DPV}$ & electrochemical sensor of Ade & [99] \\
\hline GCE & $\mathrm{TiO}_{2}$ nanobelts & - & - & $\mathrm{CV}, \mathrm{DPV}$ & analysis of DNA & [154] \\
\hline CPE, & SWCNT/cobalt phthalocyanine & - & $130 \mathrm{nM}$ & $\mathrm{CV}, \mathrm{DPV}$ & detection of DNA hybridization & [171] \\
\hline GCE & MWCNT & - & $20 \mathrm{nM}$ & $\mathrm{LSV}, \mathrm{CV}$ & analysis of DNA & [155] \\
\hline PeGE & $\mathrm{SnO}_{2}$ NPS-poly (vinylferrocenium) & - & - & DPV & DNA hybridization & [172] \\
\hline PyGE, HOPG & - & - & - & $\mathrm{CV}$ & electrode reaction mechanism of Gua & {$[17]$} \\
\hline PeGE & - & - & - & DPV & DNA interaction with Pd and Pt complexes & [26] \\
\hline PyGE & SWCNT & - & - & $0.17 \mathrm{nM}$ & simultaneous determination of Gua and 8-hydroxyguanine & [124] \\
\hline GCE & CdS-chitosan & - & nM range & DPV & analysis of DNA damage & [28] \\
\hline graphene NF & $\mathrm{CNT}$ & - & - & - & analysis of DNA & [93] \\
\hline GCE & SWCNT & $40-110 \mathrm{nM}$ & $3 \mathrm{nM}$ & - & DNA hybridization biosensor & [173] \\
\hline GCE & MWCNT & - & - & - & Gua in human prostate cancer (PC-3) cell suspension & [174] \\
\hline GCE & DNA/MWCNT & - & - & $\mathrm{CV}, \mathrm{DPV}, \mathrm{SWV}$ & monitoring of phenolic pollutants & [156] \\
\hline GCE, AuE, ITO & MWCNT/poly(neofuchsin) & - & - & $\mathrm{CV}, \mathrm{DPV}$ & - & [84] \\
\hline GCE & $\beta$-cyclodextrin/MWCNT & - & $0.75 \mathrm{nM}$ & DPV & - & [157] \\
\hline $\begin{array}{l}\text { SAE, PtE, } \\
\text { AuE, GCE }\end{array}$ & - & - & - & - & construction of electrochemical multisensors & [31] \\
\hline PeGE & SWCNT & - & - & DPV, EIS & interaction between daunorubicin and dsDNA & [175] \\
\hline
\end{tabular}


Table 4. Cont.

\begin{tabular}{|c|c|c|c|c|c|c|}
\hline Electrode & Modification & $\begin{array}{c}\text { Range of Linear } \\
\text { Concentration Dependence }\end{array}$ & $\begin{array}{c}\text { Detection } \\
\text { Limit }\end{array}$ & Method & Application & Ref \\
\hline GCE & MWCNT, Au NPS & $0.008-2.0 \mu \mathrm{M}$ & $5 \mathrm{nM}$ & $\mathrm{CV}$ & analysis of milk, plasma and urine & [158] \\
\hline $\mathrm{CPE}$ & molybdenum $(\mathrm{VI})$ complex- $\mathrm{TiO}_{2}$ nanoparticle & $7.0-200 \mathrm{nM}$ & $3.4 \mathrm{nM}$ & $\begin{array}{l}\mathrm{CV}, \mathrm{DPV}, \\
\mathrm{CPA}, \mathrm{CHC}\end{array}$ & detection of Gua at nanomolar levels & [176] \\
\hline GCE & $\mathrm{CNTs} / \mathrm{La}(\mathrm{OH})_{3}$ & - & $260 \mathrm{nM}$ & $\mathrm{CV}, \mathrm{DPV}$ & analysis of DNA & [159] \\
\hline GCE, AuE, TOE & MWCNT, Au NPS, hydroxypropyl- $\beta$-cyclodextrin & - & - & CV, DPV & electrochemical characterizations and surface morphology studies & [160] \\
\hline GCE & SWCNT/poly(acridine orange) & - & $0.9 \mathrm{nM}$ & CV, DPV & simultaneous determination of Ade in DNA & [161] \\
\hline PyGE & $\beta$-cyclodextrin/CNT & - & $0.1 \mathrm{mg} / \mathrm{mL}$ & DPV & simultaneous or individual determination of Ade & [120] \\
\hline GCE & Carbon $_{60}$ & $0.5-100 \mu \mathrm{M}$ & $60 \mathrm{nM}$ & $\mathrm{CV}$ & determination of Gua & [165] \\
\hline SPE & MWCNT & - & - & $\mathrm{CV}$ & detection DNA and RNA & [162] \\
\hline GCE & SWCNT & - & - & $\mathrm{CV}, \mathrm{DPV}$ & analysis of DNA & [163] \\
\hline $\begin{array}{c}\text { nanoelectrode } \\
\text { arrays }\end{array}$ & MWCNT nanoelectrode arrays embedded in an $\mathrm{SiO}_{2}$ matrix & - & - & - & $\begin{array}{l}\text { disposable chips for rapid molecular analysis based on the } \\
\text { Gua oxidation }\end{array}$ & [177] \\
\hline GCE & SWCNT & - & - & CV, DPV & analysis of DNA & [164] \\
\hline $\begin{array}{c}\text { nanoelectrode } \\
\text { arrays }\end{array}$ & MWCNT nanoelectrode arrays embedded in an $\mathrm{SiO}_{2}$ matrix & - & - & - & detection of DNA PCR amplicons & [178] \\
\hline \multicolumn{7}{|c|}{ XANTHINE } \\
\hline GCE & luteolin/MWCNT & - & $0.65 \mu \mathrm{M}$ & CV, DPV & detection of xanthine & [179] \\
\hline GCE & MWCNT & $0.2-10 \mu \mathrm{M}$ & $0.1 \mu \mathrm{M}$ & $\mathrm{CV}$ & detection of xanthine & [180] \\
\hline GCE & $\mathrm{PAP} / \mathrm{RGO}$ & - & $0.5 \mu \mathrm{M}$ & $\mathrm{CV}$ & detection of xanthine & [181] \\
\hline GCE & poly (pyrocatechol violet)/carboxyl MWCNT & - & $500 \mathrm{nM}$ & DPV & human serum samples & [40] \\
\hline ultra-thin $\mathrm{CPE}$ & SWCNT/poly(azure I) & $0.2-100 \mu \mathrm{M}$ & $600 \mathrm{nM}$ & $\mathrm{CV}$ & human urine samples & [182] \\
\hline GCE & MWCNT, SWCNT & $200 \mu \mathrm{M}$ & $134 \mathrm{nM}$ & DPV & fish samples & [183] \\
\hline \multicolumn{7}{|c|}{ HYPOXANTHINE } \\
\hline GCE & reduced graphene oxide attached through 1,6-hexadiamine & - & $320 \mathrm{nM}$ & DPV & human blood plasma and urine & [184] \\
\hline GCE & poly(L-arginine)/graphene composite film & $0.20-20 \mu \mathrm{M}$ & $10 \mathrm{nM}$ & DPV & hypoxan in human urine & [185] \\
\hline GCE & poly (pyrocatechol violet)/carboxyl MWCNT & - & $20 \mathrm{nM}$ & DPV & human serum samples & [40] \\
\hline ultra-thin CPE & SWCNT/poly(azure I) & $0.4-100 \mu \mathrm{M}$ & $28 \mathrm{nM}$ & $\mathrm{CV}$ & human urine samples & [182] \\
\hline GCE & MWCNT, SWCNT & $150 \mu \mathrm{M}$ & $2.87 \mu \mathrm{M}$ & DPV & fish samples & [183] \\
\hline
\end{tabular}


The achieved LOD was $0.98 \mu \mathrm{M}$. Later, Goyal et al. [55] demonstrated a fullerene-C60 modified GCE for the concurrent determination of Gua and Ade. The LODs achieved were $0.14 \mu \mathrm{M}$ and $0.3 \mu \mathrm{M}$, respectively. The observed detection limits were rather high. However, Xiao et al. [186] used a novel composite film by electrochemically coupling Au NPs on OMIMPF6-MWCNT film coated GCE for the simultaneous determination of Gua and Ade. The LODs achieved were $0.005 \mu \mathrm{M}$ for both nucleobases.

Furthermore, Fan et al. [99] demonstrated a titanium oxide $\mathrm{TiO}_{2} /$ graphene nanocomposite for electrochemical sensing of purine nucleobases-Ade and Gua. The NPs and graphene together enhanced the electrochemical activity and voltammetric response and the LODs achieved were 0.10 and $0.15 \mu \mathrm{M}$ for Ade and Gua, respectively. The $\mathrm{TiO}_{2} /$ graphene composite plays an essential role for enhancing the electrochemical activity of purine nucleobases. The enhanced voltammetric oxidation signals by $\mathrm{TiO}_{2}$ /graphene nanocomposite significantly facilitate the electron transport and provoke the electrochemical signals of Ade and Gua [99]. El-Said et al. [138] developed an electrochemical sensor for the electrochemical detection of Ade and Gua and an excellent electrocatalytic activity was accomplished with a LOD of Ade $(500 \mathrm{nM})$ and Gua $(250 \mathrm{nM})$. Recently, Li et al. fabricated an electrochemical biosensor by electropolymerizing Ag ions and melamine monomer on the GCE surface (Ag-PMel/GCE) for the simultaneous determination of Ade and Gua. The electrochemical oxidative behavior of both purines was investigated by LSV and SWV. The achieved LODs were $8 \mathrm{nM}$ for Ade and Gua [139]. Nanosilver possesses important characteristics as a metal nanomaterial, including the unique property of accelerating electron transport and biocompatibility, which allow electrostatic electron transfer with the electrode.

\subsection{Self-Assembled Monolayers (SAMs)}

Spontaneously arranged molecular assemblies of organic molecules in liquid phase or gas phase onto solid surfaces form self-assembled monolayers (SAMs). This provides a surface modification in a convenient and flexible way by readily lowering the surface-free energy of the substrate [187]. The molecules involved to form SAMs possess a distinct affinity with the substrate. The molecules adsorbed on the surface consist of a head group which facilitates interaction with the substrate. A broadly studied class of SAMs comes from adsorption of alkanethiols on gold [188,189]. Sowerby et al. [190] demonstrated a self-assembled monolayer of Ade and Gua on graphite.

Zou et al. [23] developed a voltammetric sensor for Ade and Gua by using GCE modified with tetraoxocalix[2]arene[2]triazine and observed a detection limit for Gua equal to $0.08 \mu \mathrm{M}$, whereas Jeevagan et al. [191] modified the GCE surface by using SAMs of 1,8,15,22-tetraaminophthalocyanatonickel(II) $\left(4 \alpha-\mathrm{Ni}^{\mathrm{II}} \mathrm{TAPc}\right)$ and achieved an enhanced electrocatalytic activity with a detection limit of $0.03 \mu \mathrm{M}$. The SAMs enhance the oxidation signals of Gua by enhancing its oxidation current in contrast to the bare electrode.

\subsection{Metallic Ions}

When copper (II) is reduced in the presence of some purine derivatives to copper (I), it can react with these ligands forming a complex compound. The product of this electroreduction has limited stability but can be accumulated on the electrode surface. By changing the electrode potential in the positive direction the $\mathrm{Cu}$ (I) is oxidized back to $\mathrm{Cu}$ (II), thus giving rise to an oxidation voltammetric 
peak reflecting the presence of copper in the solution. When the purine derivative studied provides an oxidation signal in the absence of $\mathrm{Cu}$ (II) and then this signal is simultaneously enhanced in the presence of $\mathrm{Cu}$ (II), thus reflecting the amount of purine derivatives in the solution. The former peak appears at a less positive potential ( $c a .0 .4 \mathrm{~V}$ in neutral or slightly acidic medium) due to the dissolution of the $\mathrm{Cu}$ (I)-purine complex being formed at the electrode at a sufficient starting potential and accumulation time, the latter peak being located close to the original oxidation signal of analyzed purine (Figure 5).

\section{Bare electrode}
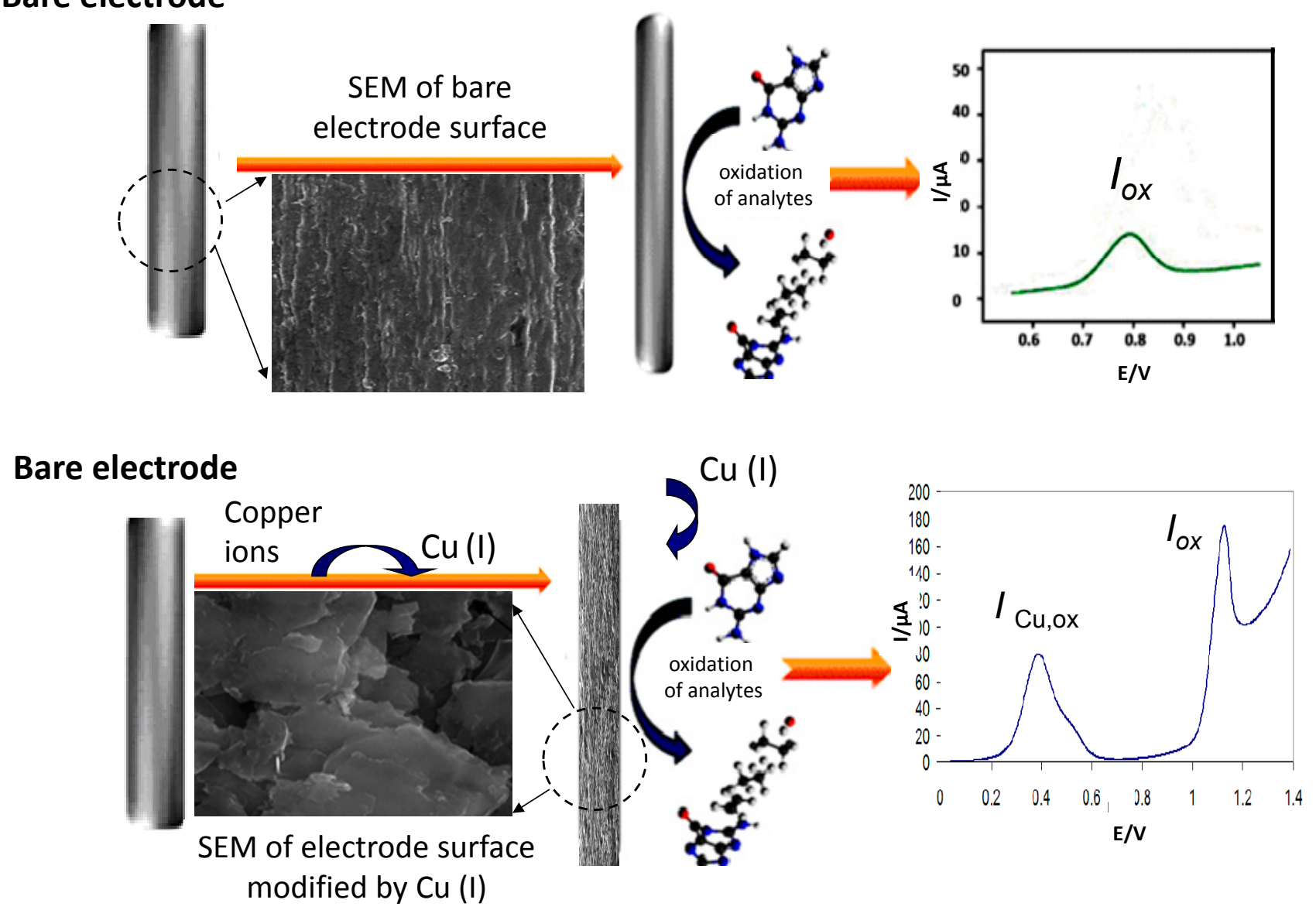

Figure 5. Voltammetric responses of oxidation processes of $\mathrm{Cu}(\mathrm{I})$-purine complexes and their corresponding purines on pencil graphite electrodes (PeGEs).

In the case of Xan, an electrochemical anodic stripping procedure for ultra-trace assay in the presence of $\mathrm{Cu}(\mathrm{II})$ at a glassy carbon electrode (GCE) was described [58]. The $\mathrm{Cu}$ (I)-Xan compound accumulated on the GCE was again dissolved by the oxidation of $\mathrm{Cu}$ (I) to $\mathrm{Cu}$ (II) and the concentration of Xan in the vicinity of the GCE increased. The results enabled us to use the measurement of the oxidation peak current as the basis of a simple, accurate and rapid method of Xan determination [58]. Differences between voltammetric signals of Ade and Xan depending on the absence and presence of $\mathrm{Cu}$ (II) are shown in Figure 6.

Our approach in electrochemical analysis of purine derivatives in the presence of copper is frequently based on the adsorptive stripping voltammetric (AdSV) technique in connection with elimination voltammetry with linear scan (EVLS) [192-196]. It has been known that AdSV enables 
measurements in a low concentration of analytes using its enhancement at the electrode by adsorptive forces. On the other hand, EVLS is a data-processing technique, which enables the elimination of selected partial voltammetric currents and the conservation of another one contributing to the increase of current sensitivity, expansion of the electrode potential range (potential window), and separation of overlapped voltammetric signals. The basic idea of the elimination procedure is based on the different dependencies of various voltammetric current components on the scan rate. The elimination result can be achieved by a function obtained by linear combination of total voltammetric currents measured at different scan rates [192-196].

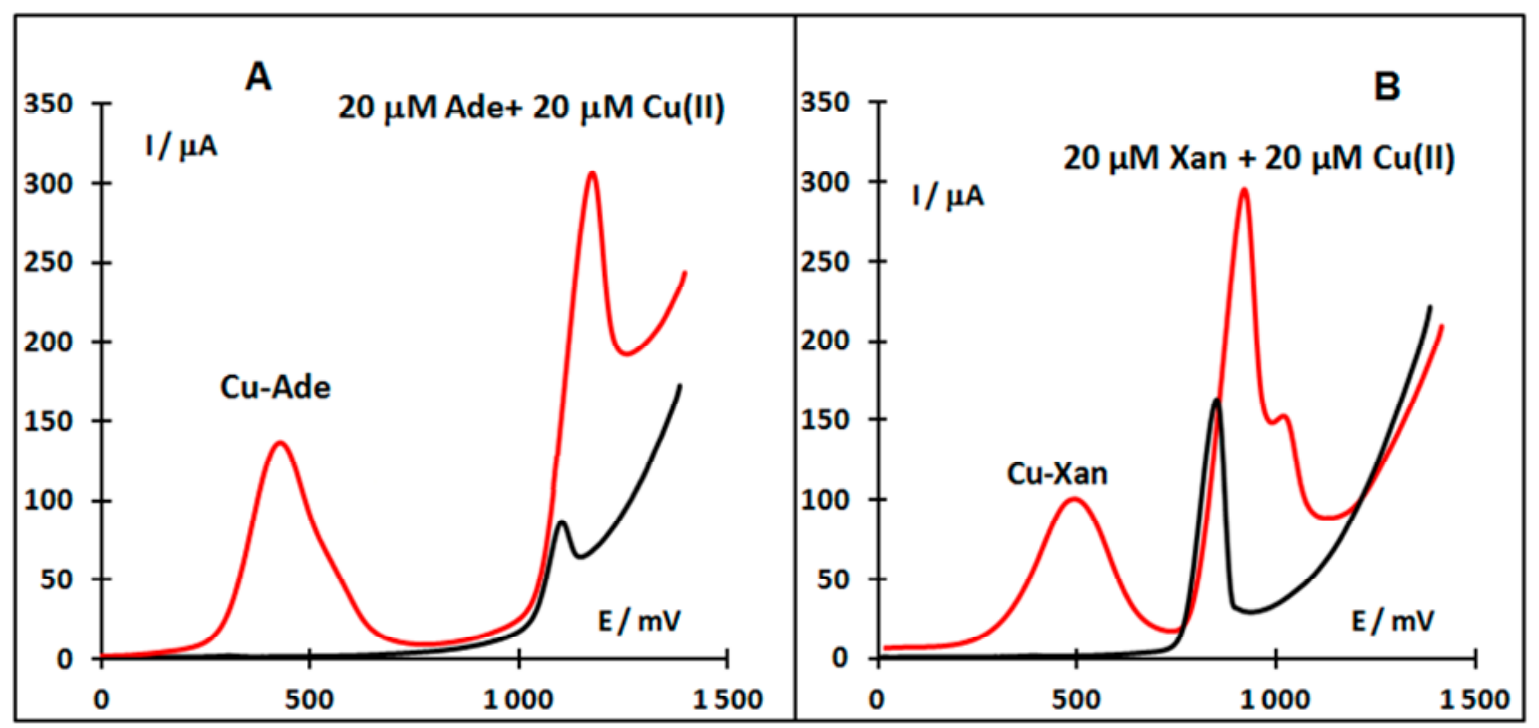

Figure 6. Linear sweep voltammograms of Ade (A) and Xan (B) in the absence (black line) or presence (red line) of $\mathrm{Cu}(\mathrm{II})$ ions. Acetate buffer $\mathrm{pH} 5.1$; scan rate $800 \mathrm{mV} / \mathrm{s}$; $\mathrm{c}_{\text {Ade }}=20 \mu \mathrm{M}$, $\mathrm{c}_{\mathrm{Xan}}=20 \mu \mathrm{M}, \mathrm{c}_{\mathrm{Cu}}(\mathrm{II})=20 \mu \mathrm{M}$.

In our previous papers we showed that analysis of purine nucleobases and their derivatives is possible at different carbon electrodes. We proved that on a paraffin-impregnated graphite electrode (PIGE) in chloride or bromide solutions ( $\mathrm{pH}$ 6), the redox process of $\mathrm{Cu}(\mathrm{II})$ proceeds with two cathodic and two anodic potentially separated signals [197]. According to the elimination function E4, eliminating the kinetic and capacitive current components and conserving the diffuse current component provides the possibility of increasing current sensitivity and changing peaks into well-readable peak-counterpeaks [197]. It was suggested that the first cathodic peak corresponds to the reduction $\mathrm{Cu}(\mathrm{II})+\mathrm{e}^{-} \rightarrow \mathrm{Cu}(\mathrm{I})$ with the possibility of fast disproportionation $2 \mathrm{Cu}(\mathrm{I}) \rightarrow \mathrm{Cu}(\mathrm{II})+\mathrm{Cu}(0)$. The $\mathrm{E} 4$ of the second cathodic peak signalized an electrode process controlled by a surface reaction. Anodic stripping voltammetry (ASV) on PIGE was carried out at potentials where the reduction of copper ions took place and $\mathrm{Cu}(\mathrm{I})$-purine complexes were formed. By using ASV and CSV in combination with EVLS, the sensitivity of $\mathrm{Cu}(\mathrm{I})$-purine complex detection was enhanced relative to either ASV or CSV alone, resulting in higher peak currents of more than one order of magnitude. Our results showed that EVLS in connection with the stripping procedure is useful for both qualitative and quantitative microanalysis of purine derivatives and can also reveal details of the electrode processes studied [197]. 
On the other hand, for electrochemical analysis of aminopurines (Ade, 2-aminopurine, 2,6-diaminopurine) and their complexes with $\mathrm{Cu}(\mathrm{I})$ we used a pencil graphite electrode (PeGE). The anodic process of the sparingly soluble $\mathrm{Cu}(\mathrm{I})$-aminopurine complex, corresponding to the oxidation of $\mathrm{Cu}(\mathrm{I})$ to $\mathrm{Cu}(\mathrm{II})$, takes place in the potential range between 0.4 and $0.5 \mathrm{~V}$. At more positive potentials the aminopurines provide voltammetric peaks in the order 2,6-diaminopurine $(\sim 0.85 \mathrm{~V}), 2$-aminopurine $(\sim 1.0 \mathrm{~V})$, and adenine $(\sim 1.10 \mathrm{~V})$, resulting from the oxidation of the purine ring. The appropriate complex of $\mathrm{Cu}(\mathrm{I})$-aminopurine has a synergic effect on the height of these peaks. The stability of the accumulated complex layer was investigated by the adsorptive transfer stripping technique. The results showed that PeGE in connection with EVLS can be an excellent prototype for a cheap and fast-working sensor for aminopurines in the presence of copper [198].

Quite recently, we analyzed at the same electrode voltammetric responses of Xan and its N-methyl derivatives (1-mXan, 3-mXan, 7-m Xan, 9-mXan) in the presence of $\mathrm{Cu}(\mathrm{II})$ ions. For electroanalytical monitoring, linear sweep voltammetry (LSV) and cyclic voltammetry (CV) in connection with the EVLS were used. All substances are oxidized on PeGE providing oxidation peaks in the absence of $\mathrm{Cu}$ (II) between $0.83 \mathrm{~V}$ (Xan) and $1.08 \mathrm{~V}$ (7-mXan). Electrochemically produced $\mathrm{Cu}$ (I) ions give rise to new oxidation peaks corresponding to the oxidation of the $\mathrm{Cu}(\mathrm{I})$-purine complex at less positive potentials between $0.32 \mathrm{~V}(9-\mathrm{mXan})$ and $0.41 \mathrm{~V}$ (Xan), while the former oxidation purine peaks are significantly increased. Peak-counterpeak EVLS signals reflect the irreversible charge transfer processes proceeding in an adsorbed state, and this fact confirms the suggested mechanism of electrode processes. The effect of scan rate was studied in order to evaluate the nature of the oxidation peak and to estimate kinetic parameters such as the charge transfer coefficient and the heterogeneous rate constant. The position of the methyl group on the Xan skeleton is responsible not only for changes of oxidation peak height and peak potentials but also for the mechanism of the corresponding oxidation processes [199].

PeGE was also used for voltammetric study of the 6-benzylaminopurine (BAP)/Cu(I) system. On the case of BAP, which is an adenine-type cytokinin that elicits cell division in plants and possesses antitumor activity when forming complexes with different transition metal ions as $\mathrm{Cu}(\mathrm{I})$ [200], it was shown that electrochemical analysis in connection with EVLS allows to propose the stoichiometry of the possible complexes formed and the mechanism for total electrode reactions of the BAP/Cu(I) system.

Ade detection was also performed at a nanostructured copper electrode prepared by electroplating in a porous membrane and characterized by several other methods including scanning electron microscopy, energy-dispersive X-ray spectroscopy, and electrochemical impedance spectroscopy. The research on the nanostructured copper electrode contributes to the development of advanced biosensors, which could be an environmentally safe alternative to mercury for the detection of adenine by voltammetric techniques [201].

\section{Conclusions and Future Perspectives}

Achieving high sensitivity, selectivity and cost effectiveness has always been the primary goal to design biosensing methods. Electroanalytical methods are simple, sensitive, fast, cost-effective, reliable, and efficient compared to other analytical methods. As we have summarized in this review, the integration of surface modification has opened up new possibilities in the field of electrochemical biosensing. 
Figure 7 shows the range of diversities in electrochemical methods starting from buffer solution, different types of electrode with surface modifications, and indicates a very sophisticated system which needs to be more characterized at each level.

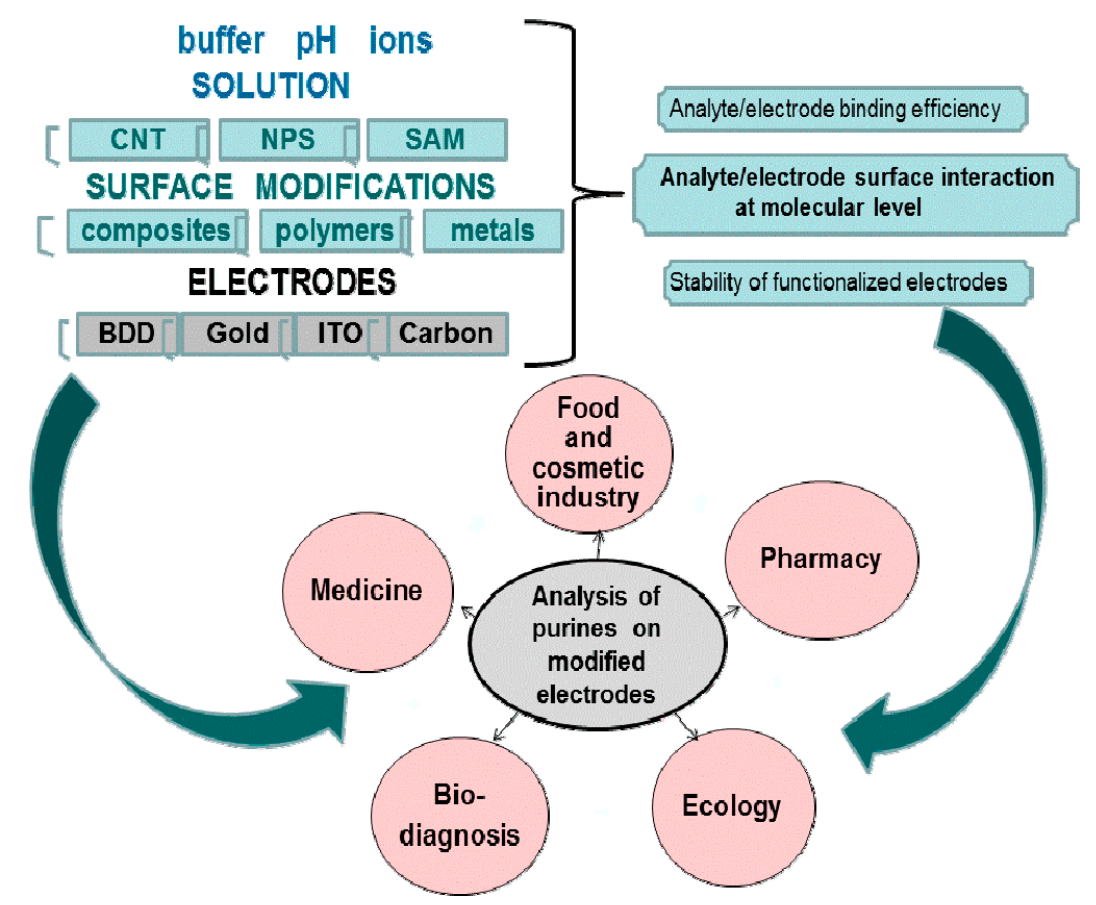

Figure 7. Application of electrochemical sensing of purine nucleobases and their analogues.

Nanomaterials provide an outstanding advantage over other types of modifications due to their outstanding electrochemical properties. From many papers it follows that any sensitive detection of purine derivatives is related to structure and chemistry on the electrode surface. It is desirable to know how the molecules are arranged on electrode surfaces and how these molecules interact with the electrode surface, i.e., how they are distributed and whether the interaction between analytes and functionalized solid electrodes is strong enough to provide stability. Moreover, we need more efforts to develop an understanding of what happens at the molecular level during analyte/electrode surface interaction. Besides the range of electrodes, carbon electrodes have been used most extensively and also carbon nanomaterials have been used for modification. The critical point is besides the evident differences between carbon nanomaterials (SWCNTs, MWCNTs and graphene); the results obtained from different experiments apparently cause confusion and problems in designing an efficient electrochemical system for biosensing. There is a need, in order to develop a robust biosensing approach, to focus and concentrate on the characterization of carbon materials with different carbon nanomaterial functionalization. Obviously, the complications arisen from heterogeneous carbon nanomaterials will undoubtedly advance our understanding and therefore will increase our understanding to develop possible applications in the field of biosensing.

\section{Acknowledgment}

This research was supported by the following projects: LH 13053 KONTAKT II of the Ministry of Education, Youth, and Sports of the Czech Republic (MEYS CR), SIX CZ.1.05/2.1.00/03.0072, and 
the Project Postdoc I, reg. No. CZ.1.07/2.3.00/30.0009 which is co-financed by the European Social Fund and the state budget of the Czech Republic.
Abbreviations
Ade adenine
Ado adenosine
AMP adenosine monophosphate
AuE gold electrode
BAP 6-benzylaminopurine
BDD boron doped diamond
BDDE boron-doped diamond electrode
CILE carbon ionic liquid electrode
CNT carbon nanotubes
CV cyclic voltammetry
DPV differential pulse voltammetry
EIS electrochemical impedance spectroscopy
GCE glassy carbon electrode
Gua guanine
Guo guanosine
Ino inosine
ITO indium tin oxide
LOD limit of detection
MWCNT multi-walled carbon nanotubes
NPs nanoparticles
ODN oligodeoxynucleotide
PeGE pencil graphite electrode
PtE platinum electrode
PyGE pyrolytic graphite electrode
SAE solid amalgam electrode
SAM self-assembled monolayer
SPE screen-printed electrode
SQV square-wave voltammetry
SWCNT single-walled carbon nanotubes
Xan xanthine
Xao xanthosine

\section{Conflicts of Interest}

The authors declare no conflict of interest. 


\section{References}

1. Robak, T. Novel drugs for chronic lymphoid leukemias: Mechanism of action and therapeutic activity. Curr. Med. Chem. 2009, 16, 2212-2234.

2. Robak, T.; Korycka, A.; Kasznicki, M.; Wrzesien-Kus, A.; Smolewski, P. Purine nucleoside analogues for the treatment of hematological malignancies: Pharmacology and clinical applications. Curr. Cancer Drug Targets 2005, 5, 421-444.

3. Palecek, E.; Jelen, F. Electrochemistry of nucleic acids and development of DNA sensors. Crit. Rev. Anal. Chem. 2002, 32, 261-270.

4. Palecek, E.; Jelen, F. Electrochemistry of nucleic acids. In Electrochemistry of Nucleic Acids and Proteins. Towards Electrochemical Sensors for Genomics and Proteomics; Palecek, E., Scheller, F., Wang, J., Eds.; Elsevier: New York, NY, USA, 2005; Volume 1, pp. 74-173.

5. Oliveira-Brett, A.M.; Piedade, J.A.P.; Silva, L.A.; Diculescu, V.C. Voltammetric determination of all DNA nucleotides. Anal. Biochem. 2004, 332, 321-329.

6. Stempkowska, I.; Ligaj, M.; Jasnowska, J.; Langer, J.; Filipiak, M. Electrochemical response of oligonucleotides on carbon paste electrode. Bioelectrochemistry 2007, 70, 488-494.

7. Wang, J. Stripping Analysis. Principles, Instrumentation and Applications; VCH: Deerfield Beach, FL, USA, 1985.

8. Wang, J. Electroanalysis and biosensors. Anal. Chem. 1999, 71, 328R-332R.

9. Dryhurst, G. Electrochemistry of Biological Molecules; Academic Press: New York, NY, USA, 1977.

10. Goyal, R.N.; Bishnoi, S.; Singh, R.K. Electrochemical sensor for the simultaneous voltammetric determination of adenosine and adenine. Indian J. Chem. 2011, 50, 1026-1034.

11. Goncalves, L.M.; Batchelor-McAuley, C.; Barros, A.A.; Compton, R.G. Electrochemical oxidation of adenine: A mixed adsorption and diffusion response on an edge-plane pyrolytic graphite electrode. J. Phys. Chem. C 2010, 114, 14213-14219.

12. Goyal, R.N.; Chatterjee, S.; Bishnoi, S. Voltammetric determination of 2'-deoxyadenosine and adenine in urine of patients with hepatocellular carcinoma using fullerene- $C$-60-modified glassy carbon electrode. Electroanalysis 2009, 21, 1369-1378.

13. Goyal, R.N.; Kumar, A.; Mittal, A. Oxidation chemistry of adenine and hydroxyadenines at pyrolytic - graphite electrodes. J. Chem. Soc.-Perkin Trans. 1991, 2, 1369-1375.

14. Oliveira-Brett, A.M.; Diculescu, V.; Piedade, J.A.P. Electrochemical oxidation mechanism of guanine and adenine using a glassy carbon microelectrode. Bioelectrochemistry 2002, 55, 61-62.

15. Goyal, R.N.; Sangal, A. Electrochemical investigations of adenosine at solid electrodes. J. Electroanal. Chem. 2002, 521, 72-80.

16. Goyal, R.N.; Sangal, A. Electrochemical oxidation of adenosine monophosphate at a pyrolytic graphite electrode. J. Electroanal. Chem. 2003, 557, 147-155.

17. Li, Q.; Batchelor-Mcauley, C.; Compton, R.G. Electrochemical oxidation of guanine: Electrode reaction mechanism and tailoring carbon electrode surfaces to switch between adsorptive and diffusional responses. J. Phys. Chem. B 2010, 114, 7423-7428. 
18. Qin, X.; Liu, X.; Hong-Bo, L.; Li-Na, Y.; Xiaoya, H. Electrochemical determination of purine and pyrimidine DNA bases based on the recognition properties of azocalix[4]arene. Biosens. Bioelectron. 2013, 42, 355-361.

19. Svorc, L.; Kalcher, K. Modification-free electrochemical approach for sensitive monitoring of purine DNA bases: Simultaneous determination of guanine and adenine in biological samples using boron-doped diamond electrode. Sens. Actuators B Chem. 2014, 194, 332-342.

20. Muti, M.; Erdem, A.; Karagozler, A.E.; Soysal, M. 5-Amino-2-mercapto-1,3,4-thidiazole modified single-use sensors for electrochemical DNA analysis. Colloids Surf. B-Biointerfac. 2012 , 93, 116-120.

21. Liu, X.; Luo, L.; Ding, Y.; Wu, Q.; Wei, Y.; Ye, D. A highly sensitive method for determination of guanine, adenine and epinephrine using poly-melamine film modified glassy carbon electrode. J. Electroanal. Chem. 2012, 675, 47-53.

22. Brahman, P.K.; Dar, R.A.; Pitre, K.S. Voltammetric study of ds-DNA-flutamide interaction at carbon paste electrode. Arab. J. Chem. 2012, doi:10.1016/j.arabjc.2012.08.007.

23. Zou, L.N.; Li, Y.M.; Ye, B.X. Voltammetric sensing of guanine and adenine using a glassy carbon electrode modified with a tetraoxocalix[2]arene[2]triazine Langmuir-Blodgett film. Microchim. Acta 2011, 173, 285-291.

24. Song, Y.; Li, J.Z. Direct electrochemical determination of adenine using hpmft-modified glassy carbon electrode in comercial pharmaceutical products. Instrum. Sci. Technol. 2011, 39, 261-272.

25. Feng, L.J.; Zhang, X.H.; Liu, P.; Xiong, H.Y.; Wang, S.F. An electrochemical sensor based on single-stranded DNA-poly(sulfosalicylic acid) composite film for simultaneous determination of adenine, guanine, and thymine. Anal. Biochem. 2011, 419, 71-75.

26. Sonmez, M.; Elebi, M.; Yardm, Y.; Enturk, Z. Palladium(II) and platinum(II) complexes of a symmetric Schiff base derived from 2,6-diformyl-4-methylphenol with N-aminopyrimidine: Synthesis, characterization and detection of DNA interaction by voltammetry. Eur. J. Med. Chem. 2010, 45, 4215-4220.

27. Rawson, F.J.; Jackson, S.K.; Hart, J.P. Voltammetric behavior of DNA and its derivatives using screen printed carbon electrodes and its possible application in genotoxicity screening. Anal. Lett. 2010, 43, 1790-1800.

28. Ferancova, A.; Rengaraj, S.; Kim, Y.; Labuda, J.; Sillanpaa, M. Electrochemical determination of guanine and adenine by CdS microspheres modified electrode and evaluation of damage to DNA purine bases by UV radiation. Biosens. Bioelectron. 2010, 26, 314-320.

29. Zhang, R.; Jin, G.D.; Hu, X.Y. Sensitive determination of adenine on poly(amidosulfonic acid)modified glassy carbon electrode. J. Solid State Electrochem. 2009, 13, 1545-1552.

30. Xu, Q.; Sun, M.; Du, Q.; Bian, X.; Chen, D.; Hu, X. Tailoring the electrode by cysteic acid for sensitive determination of adenine in vitamin B4 tablet. Curr. Pharm. Anal. 2009, 5, 190-196.

31. Navratil, T.; Yosypchuk, B.; Barek, J. A multisensor for electrochemical sequential autonomous automatic measurements. Chem. Anal. 2009, 54, 3-17.

32. Kamel, A.H.; Moreira, F.T.C.; Delerue-Matos, C.; Sales, M.G.F. Electrochemical determination of antioxidant capacities in flavored waters by guanine and adenine biosensors. Biosens. Bioelectron. 2008, 24, 591-599. 
33. Zari, N.; Mohammedi, H.; Amine, A.; Ennaji, M.M. DNA hydrolysis and voltammetric determination of guanine and adenine using different electrodes. Anal. Lett. 2007, 40, 1698-1713.

34. Honeychurch, K.C.; O’Donovan, M.R.; Hart, J.P. Voltammetric behaviour of DNA bases at a screen-printed carbon electrode and its application to a simple and rapid voltammetric method for the determination of oxidative damage in double stranded DNA. Biosens. Bioelectron. 2007, 22, 2057-2064.

35. Dolinnaya, N.G.; Jan, M.R.; Kawde, A.N.; Oretskaya, T.S.; Tashlitsky, V.N.; Wang, J. Electrochemical detection of abasic site-containing DNA. Electroanalysis 2006, 18, 399-404.

36. Bagni, G.; Ravera, M.; Osella, D.; Mascini, M. Electrochemical biosensors as a screening tool of in vitro DNA-drug interaction. Curr. Pharm. Anal. 2005, 1, 217-224.

37. Karadeniz, H.; Gulmez, B.; Sahinci, F.; Erdem, A.; Kaya, G.I.; Unver, N.; Kivcak, B.; Ozsoz, M. Disposable electrochemical biosensor for the detection of the interaction between DNA and lycorine based on guanine and adenine signals. J. Pharm. Biomed. Anal. 2003, 33, 295-302.

38. Ivandini, T.A.; Sarada, B.V.; Rao, T.N.; Fujishima, A. Electrochemical oxidation of underivatized-nucleic acids at highly boron-doped diamond electrodes. Analyst 2003, 128, 924-929.

39. Golea, D.A.; Diculescu, V.C.; Enache, A.T.; Butu, A.; Tugulea, L.; Brett, A.M.O. Electrochemical evaluation of dsDNA-Liposomes interactions. Dig. J. Nanomater. Biostruct. 2012, 7, 1333-1342.

40. Yan, F.F.; Wang, F.; Chen, Z.L. Aptamer-based electrochemical biosensor for label-free voltammetric detection of thrombin and adenosine. Sens. Actuators B Chem. 2011, 160, 1380-1385.

41. Gao, H.W.; Duan, Y.Y.; Xi, M.Y.; Sun, W. Voltammetric detection of guanosine and adenosine using a carbon paste electrode modified with 1-ethyl-3-methylimidazolium ethylsulfate. Microchim. Acta 2011, 172, 57-64.

42. Sun, W.; Duan, Y.Y.; Li, Y.Z.; Zhan, T.R.; Jiao, K. Electrochemistry and Voltammetric Determination of Adenosine with N-Hexylpyridinium Hexafluorophosphate Modified Electrode. Electroanalysis 2009, 21, 2667-2673.

43. Topkaya, S.N.; Ozkan-Ariksoysal, D.; Kosova, B.; Ozel, R.; Ozsoz, M. Electrochemical DNA biosensor for detecting cancer biomarker related to glutathione S-transferase P1 (GSTP1) hypermethylation in real samples. Biosens. Bioelectron. 2012, 31, 516-522.

44. Dogan-Topal, B.; Uslu, B.; Ozkan, S.A. Voltammetric studies on the HIV-1 inhibitory drug Efavirenz: The interaction between dsDNA and drug using electrochemical DNA biosensor and adsorptive stripping voltammetric determination on disposable pencil graphite electrode. Biosens. Bioelectron. 2009, 24, 2358-2364.

45. Yardim, Y.; Senturk, Z.; Ozsoz, M.; Ozdemir, K.; Atalan, E. Trace determination of DNA in an amaryllidaceae plant, Narcissus tazetta by square-wave stripping voltammetry based on guanine signal. Fabad J. Pharm. Sci. 2007, 32, 159-165.

46. Nowicka, A.M.; Zabost, E.; Donten, M.; Mazerska, Z.; Stojek, Z. Electroanalytical and spectroscopic procedures for examination of interactions between double stranded DNA and intercalating drugs. Anal. Bioanal. Chem. 2007, 389, 1931-1940. 
47. Abbaspour, A.; Baramakeh, L.; Nabavizadeh, S.M. Development of a disposable sensor for electrocatalytic detection of guanine and ss-DNA using a modified sol-gel screen-printed carbon electrode. Electrochim. Acta 2007, 52, 4798-4803.

48. Yabuki, S.; Sato, Y.; Niwa, O. Measurement of DNA amount on gold plate based on the oxidation current of guanine. Bunseki Kagaku 2006, 55, 975-978.

49. Bagni, G.; Osella, D.; Sturchio, E.; Mascini, M. Deoxyribonucleic acid (DNA) biosensors for environmental risk assessment and drug studies. Anal. Chim. Acta 2006, 573-574, 81-89.

50. Ozsoz, M.; Erdem, A.; Ozkan, D.; Kara, P.; Karadeniz, H.; Meric, B.; Kerman, K.; Girousi, S. Allele-specific genotyping by using guanine and gold electrochemical oxidation signals. Bioelectrochemistry 2005, 67, 199-203.

51. Wang, J.; Chen, G.; Muck, A.; Shin, D.C.; Fujishima, A. Microchip capillary electrophoresis with a boron-doped diamond electrode for rapid separation and detection of purines. J. Chromatogr. A 2004, 1022, 207-212.

52. Ferapontova, E.E. Electrochemistry of guanine and 8-oxoguanine at gold electrodes. Electrochim. Acta 2004, 49, 1751-1759.

53. Ozsoz, M.; Erdem, A.; Kara, P.; Kerman, K.; Ozkan, D. Electrochemical biosensor for the detection of interaction between arsenic trioxide and DNA based on guanine signal. Electroanalysis 2003, 15, 613-619.

54. Kerman, K.; Morita, Y.; Takamura, Y.; Tamiya, E. Label-free electrochemical detection of DNA hybridization on gold electrode. Electrochem. Commun. 2003, 5, 887-891.

55. Goyal, R.N.; Gupta, V.K.; Oyama, M.; Bachheti, N. Voltammetric determination of adenosine and guanosine using fullerene-C(60)-modified glassy carbon electrode. Talanta 2007, 71, $1110-1117$.

56. Yao, T.; Taniguchi, Y.; Wasa, T.; Musha, S. Anodic voltammetry and its analytical application to the detection and simultaneous determination of hypoxanthine, xanthine, and uric acid. Bull. Chem. Soc. Jpn. 1978, 51, 2937-2941.

57. Goyal, R.N. Electrochemical Oxidation of Xanthine at Solid Electrodes. Indian J. Chem. 1989, $28,467-471$.

58. Ibrahim, M.S.; Temerk, Y.M.; Kamal, M.M.; Ahmed, G.A.W.; Ibrahim, H.S.M. Ultra-sensitive anodic stripping voltammetry for the determination of xanthine at a glassy carbon electrode. Microchim. Acta 2004, 144, 249-256.

59. Ojani, R.; Alinezhad, A.; Abedi, Z. A highly sensitive electrochemical sensor for simultaneous detection of uric acid, xanthine and hypoxanthine based on poly(l-methionine) modified glassy carbon electrode. Sens. Actuators B Chem. 2013, 188, 621-630.

60. Dou, Z.Y.; Cui, L.L.; He, X.Q. Electrochimical determination of uric acid, xanthine and hypoxanthine by poly(xylitol) modified glassy carbon electrode. J. Cent. South Univ. 2014, 21, 870-876.

61. Devi, R.; Batra, B.; Lata, S.; Yadav, S.; Pundir, C.S. A method for determination of xanthine in meat by amperometric biosensor based on silver nanoparticles/cysteine modified Au electrode. Process Biochem. 2013, 48, 242-249.

62. Thangaraj, R.; Kumar, A.S. Graphitized mesoporous carbon modified glassy carbon electrode for selective sensing of xanthine, hypoxanthine and uric acid. Anal. Methods 2012, 4, 2162-2171. 
63. Pundir, C.S.; Devi, R.; Narang, J.; Singh, S.; Nehra, J.; Chaudhry, S. Fabrication of an amperometric xanthine biosensor based on polyvinylchloride membrane. J. Food Biochem. 2012, $36,21-27$.

64. Liu, Y.; Li, W.; Wei, C.; Lu, L. Preparation of a xanthine sensor based on the immobilization of xanthine oxidase on a chitosan modified electrode by cross-linking. Chin. J. Chem. 2012, 30, 1601-1604.

65. Liu, L.; Wang, H.; Bo, X.; Yang, L.; Guo, L. Electrochemistry and simultaneous detection of metabolites of purine nucleotide based on large mesoporous carbon modified electrode. Electroanalysis 2012, 24, 1401-1408.

66. Wang, Y.; Tong, L.L. Electrochemical sensor for simultaneous determination of uric acid, xanthine and hypoxanthine based on poly (bromocresol purple) modified glassy carbon electrode. Sens. Actuators B Chem. 2010, 150, 43-49.

67. Lin, L.; Song, C.; Xie, L.; Yu, L.; Wu, L.; Zhang, M.; Yang, S.; Gao, H.; Li, X. Electrochemical determination of xanthine and hypoxanthine in rat striatum with an acetylene black-dihexadecyl hydrogen phosphate composite film modified electrode by HPLC coupled with in vivo microdialysis. Microchim. Acta 2010, 170, 47-52.

68. Revin, S.B.; John, S.A. Selective determination of inosine in the presence of uric acid and hypoxanthine using modified electrode. Anal. Biochem. 2012, 421, 278-284.

69. Ivandini, T.A.; Honda, K.; Rao, T.N.; Fujishima, A.; Einaga, Y. Simultaneous detection of purine and pyrimidine at highly boron-doped diamond electrodes by using liquid chromatography. Talanta 2007, 71, 648-655.

70. Deng, C.Y.; Xia, Y.L.; Xiao, C.H.; Nie, Z.; Yang, M.H.; Si, S.H. Electrochemical oxidation of purine and pyrimidine bases based on the boron-doped nanotubes modified electrode. Biosens. Bioelectron. 2012, 31, 469-474.

71. Hason, S.; Pivonkova, H.; Vetterl, V.; Fojta, M. Label-free sequence-specific DNA sensing using copper-enhanced anodic stripping of purine bases at boron-doped diamond electrodes. Anal. Chem. 2008, 80, 2391-2399.

72. Bowden, E.F.; Hawkridge, F.M.; Chlebowski, J.F.; Bancroft, E.E.; Thorpe, C.; Blount, H.N. Cyclic voltammetry and derivative cyclic voltabsorptometry of purified horse heart cytochrome c at tin-doped indium oxide optically transparent electrodes. J. Am. Chem. Soc. 1982, 104, 7641-7644.

73. Johnston, D.H.; Glasgow, K.C.; Thorp, H.H. Electrochemical measurement of the solvent accessibility of nucleobases using electron transfer between DNA and metal complexes. J. Am. Chem. Soc. 1995, 117, 8933-8938.

74. Thorp, H.H. Cutting out the middleman: DNA biosensors based on electrochemical oxidation. Trends Biotechnol. 1998, 16, 117-121.

75. Moses, S.; Brewer, S.H.; Kraemer, S.; Fuierer, R.R.; Lowe, L.B.; Agbasi, C.; Sauthier, M.; Franzen, S. Detection of DNA hybridization on indium tin oxide surfaces. Sens. Actuators B Chim. 2007, 125, 574-580.

76. Sistare, M.F.; Holmberg, R.C.; Thorp, H.H. Electrochemical studies of polynucleotide binding and oxidation by metal complexes: Effects of scan rate, concentration, and sequence. $J$. Phys. Chem. B 1999, 103, 10718-10728. 
77. Armistead, P.M.; Thorp, H.H. Oxidation kinetics of guanine in DNA molecules adsorbed onto indium tin oxide electrodes. Anal. Chem. 2001, 73, 558-564.

78. Hong, W.; Li, H.; Yao, S.; Sun, F.; Xu, Z.H. Mediated oxidation of guanine by $[\mathrm{Ru}(\mathrm{bpy}) 2 \mathrm{dpp}]^{2+}$ and their electrochemical assembly on the ITO electrode. Electrochim. Acta 2009, 54, 3250-3254.

79. Guo, Q.Y.; Li, H.; Yang, H.Y.; Shao, J.Y. Fabrication and Photoelectrochemical Properties of $\left[\mathrm{Ru}(\mathrm{bpy})^{2} \mathrm{dppz}\right]^{2+}$ on ITO Electrode Associated with the Oxidation of Guanine. Chem. Res. Chin. Univ. 2010, 26, 649-655.

80. Goyal, R.N.; Oyama, M.; Singh, S.P. Simultaneous determination of adenosine and adenosine-5'-triphosphate at nanogold modified Indium tin oxide electrode by Osteryoung square-wave voltammetry. Electroanalysis 2007, 19, 575-581.

81. Wu, Y.; Feng, X.; Zhou, S.H.; Shi, H.Y.; Wu, H.M.; Zhao, S.J.; Song, W.B. Sensing epinephrine with an ITO electrode modified with an imprinted chitosan film containing multi-walled carbon nanotubes and a polymerized ionic liquid. Microchim. Acta 2013, 180, 1325-1332.

82. Singh, A.; Sinsinbar, G.; Choudhary, M.; Kumar, V.; Pasricha, R.; Verma, H.N.; Singh, S.P.; Arora, K. Graphene oxide-chitosan nanocomposite based electrochemical DNA biosensor for detection of typhoid. Sens. Actuators B Chem. 2013, 185, 675-684.

83. Zhao, C.Z.; Zhao, G.S.; Zhang, Z.X.; Liang, J.Y. Preparation and application of photoelectrochemical guanine sensor. Acta Chim. Sinica 2012, 70, 1401-1406.

84. Tang, C.; Umasankar, Y.; Chen, S.M. Simultaneous determination of adenine guanine and thymine at multi-walled carbon nanotubes incorporated with poly(new fuchsin) composite film. Anal. Chim. Acta 2009, 636, 19-27.

85. Fang, Y.; Wang, E. Electrochemical biosensors on platforms of graphene. Chem. Commun. 2013, 49, 9526-9539.

86. Uslu, B.; Ozkan, S.A. Solid electrodes in electroanalytical chemistry: Present applications and prospects for high throughput screening of drug compounds. Comb. Chem. High Throughput Screen. 2007, 10, 495-513.

87. Novoselov, K.S.; Geim, A.K.; Morozov, S.V.; Jiang, D.; Zhang, Y.; Dubonos, S.V.; Grigorieva, I.V.; Firsov, A.A. Electric field effect in atomically thin carbon films. Science 2004, 306, 666-669.

88. Novoselov, K.S.; Jiang, D.; Schedin, F.; Booth, T.J.; Khotkevich, V.V.; Morozov, S.V.; Geim, A.K. Two-dimensional atomic crystals. Proc. Natl. Acad. Sci. USA 2005, 102, 10451-10453.

89. Pumera, M. Graphene-based nanomaterials and their electrochemistry. Chem. Soc. Rev. 2010, 39, 4146-4157.

90. Pumera, M. Electrochemistry of graphene, graphene oxide and other graphenoids: Review. Electrochem. Commun. 2013, 36, 14-18.

91. Geim, A.K.; Novoselov, K.S. The rise of graphene. Nat. Mater. 2007, 6, 183-191.

92. Alwarappan, S.; Erdem, A.; Liu, C.; Li, C.Z. Probing the Electrochemical Properties of Graphene Nanosheets for Biosensing Applications. J. Phys. Chem. C 2009, 113, 8853-8857.

93. Ambrosi, A.; Pumera, M. Stacked graphene nanofibers for electrochemical oxidation of DNA bases. Phys. Chem. Chem. Phys. 2010, 12, 8944-8948.

94. Segal, M. Selling graphene by the ton. Nat. Nanotechnol. 2009, 4, 612-614. 
95. Shang, N.G.; Papakonstantinou, P.; McMullan, M.; Chu, M.; Stamboulis, A.; Potenza, A.; Dhesi, S.S.; Marchetto, H. Catalyst-free efficient growth, orientation and biosensing properties of multilayer graphene nanoflake films with sharp edge planes. Adv. Funct. Mater. 2008, 18, 3506-3514.

96. Allen, M.J.; Tung, V.C.; Kaner, R.B. Honeycomb carbon: A review of graphene. Chem. Rev. 2009, 110, 132-145.

97. Huang, K.J.; Niu, D.J.; Sun, J.Y.; Han, C.H.; Wu, Z.W.; Li, Y.L.; Xiong, X.Q. Novel electrochemical sensor based on functionalized graphene for simultaneous determination of adenine and guanine in DNA. Colloids Surf. B Biointerfaces 2011, 82, 543-549.

98. Randviir, E.P.; Banks, C.E. Electrochemical measurement of the DNA bases adenine and guanine at surfactant-free graphene modified electrodes. RSC Adv. 2012, 2, 5800-5805.

99. Fan, Y.; Huang, K.J.; Niu, D.J.; Yang, C.P.; Jing, Q.S. $\mathrm{TiO}_{2}$-graphene nanocomposite for electrochemical sensing of adenine and guanine. Electrochim. Acta 2011, 56, 4685-4690.

100. Yin, H.; Zhou, Y.; Ma, Q.; Ai, S.; Ju, P.; Zhu, L.; Lu, L. Electrochemical oxidation behavior of guanine and adenine on graphene-Nafion composite film modified glassy carbon electrode and the simultaneous determination. Process Biochem. 2010, 45, 1707-1712.

101. Zhou, M.; Zhai, Y.; Dong, S. Electrochemical sensing and biosensing platform based on chemically reduced graphene oxide. Anal. Chem. 2009, 81, 5603-5613.

102. Zhu, X.H.; Zeng, L.X.; Xu, M.T.; Liang, Y.; Nan, J.M. A glassy carbon electrode modified with electrochemically reduced graphene for simultaneous determination of guanine and adenine. Anal. Methods 2012, 4, 2935-2939.

103. Kang, X.; Wang, J.; Wu, H.; Liu, J.; Aksay, I.A.; Lin, Y. A graphene-based electrochemical sensor for sensitive detection of paracetamol. Talanta 2010, 81, 754-759.

104. Liu, X.; Zhang, L.; Wei, S.; Chen, S.; Ou, X.; Lu, Q. Overoxidized polyimidazole/graphene oxide copolymer modified electrode for the simultaneous determination of ascorbic acid, dopamine, uric acid, guanine and adenine. Biosens. Bioelectron. 2014, 57, 232-238.

105. Wang, H.; Bo, X.; Guo, L. Electrochemical biosensing platform based on a novel porous graphene nanosheet. Sens. Actuators B Chem. 2014, 192, 181-187.

106. Areshkin, D.A.; Gunlycke, D.; White, C.T. Ballistic transport in graphene nanostrips in the presence of disorder: Importance of edge effects. Nano Lett. 2007, 7, 204-210.

107. Rivas, G.A.; Rubianes, M.D.; Rodríguez, M.C.; Ferreyra, N.F.; Luque, G.L.; Pedano, M.L.; Miscoria, S.A.; Parrado, C. Carbon nanotubes for electrochemical biosensing. Talanta 2007, 74, 291-307.

108. Carrara, S.; Baj-Rossi, C.; Boero, C.; de Micheli, G. Do Carbon nanotubes contribute to electrochemical biosensing? Electrochim. Acta 2014, 128, 102-112.

109. Iijima, S. Helical microtubules of graphitic carbon. Nature 1991, 354, 56-58.

110. Jacobs, C.B.; Peairs, M.J.; Venton, B.J. Review: Carbon nanotube based electrochemical sensors for biomolecules. Anal. Chim. Acta 2010, 662, 105-127.

111. Gao, C.; Guo, Z.; Liu, J.H.; Huang, X.J. The new age of carbon nanotubes: An updated review of functionalized carbon nanotubes in electrochemical sensors. Nanoscale 2012, 4, 1948-1963.

112. Odom, T.W.; Huang, J.L.; Kim, P.; Lieber, C.M. Atomic structure and electronic properties of single-walled carbon nanotubes. Nature 1998, 391, 62-64. 
113. Wilder, J.W.G.; Venema, L.C.; Rinzler, A.G.; Smalley, R.E.; Dekker, C. Electronic structure of atomically resolved carbon nanotubes. Nature 1998, 391, 59-62.

114. Wang, J. Carbon-Nanotube Based Electrochemical Biosensors: A Review. Electroanalysis 2005, $17,7-14$.

115. Huang, J.S.; Liu, Y.; You, T.Y. Carbon nanofiber based electrochemical biosensors: A review. Anal. Methods 2010, 2, 202-211.

116. Gooding, J.J. Nanostructuring electrodes with carbon nanotubes: A review on electrochemistry and applications for sensing. Electrochim. Acta 2005, 50, 3049-3060.

117. Lota, G.; Fic, K.; Frackowiak, E. Carbon nanotubes and their composites in electrochemical applications. Energy Environ. Sci. 2011, 4, 1592-1605.

118. Yanez-Sedeno, P.; Riu, J.; Pingarron, J.M.; Rius, F.X. Electrochemical sensing based on carbon nanotubes. TrAC Trends Anal. Chem. 2010, 26, 939-953.

119. Yun, Y.H.; Dong, Z.Y.; Shanov, V.; Heineman, W.R.; Halsall, H.B.; Bhattacharya, A.; Conforti, L.; Narayan, R.K.; Ball, W.S.; Schulz, M.J. Nanotube electrodes and biosensors. Nano Today 2007, $2,30-37$.

120. Wang, Z.; Xiao, S.; Chen, Y. $\beta$-Cyclodextrin incorporated carbon nanotubes-modified electrodes for simultaneous determination of adenine and guanine. J. Electroanal. Chem. 2006, 589, 237-242.

121. Wu, K.B.; Fei, J.J.; Bai, W.; Hu, S.S. Direct electrochemistry of DNA, guanine and adenine at a nanostructured film-modified electrode. Anal. Bioanal. Chem. 2003, 376, 205-209.

122. Wang, P.; Wu, H.; Dai, Z.; Zou, X.Y. Simultaneous detection of guanine, adenine, thymine and cytosine at choline monolayer supported multiwalled carbon nanotubes film. Biosens. Bioelectron. 2011, 26, 3339-3345.

123. Kawde, A.N.; Saleh, T.A. Electrochemical investigation of glassy carbon paste electrode and its application for guanine and ssDNA detection. Chem. Sens. 2011, 1, 18-24.

124. Goyal, R.N.; Bishnoi, S. Sensitive voltammetric sensor for the determination of oxidative DNA damage in calf thymus DNA. Biosens. Bioelectron. 2010, 26, 463-469.

125. Goyal, R.N.; Chatterjee, S.; Rana, A.R.S. Electrochemical sensor based on oxidation of 2,8-dihydroxyadenine to monitor dna damage in calf thymus DNA. Electroanalysis 2011, 23, 1383-1390.

126. Belding, S.R.; Campbell, F.W.; Dickinson, E.J.F.; Compton, R.G. Nanoparticle-modified electrodes. Phys. Chem. Chem. Phys. 2010, 12, 11208-11221.

127. Campbell, F.W.; Compton, R.G. The use of nanoparticles in electroanalysis: an updated review. Anal. Bioanal. Chem. 2010, 396, 241-259.

128. Anker, J.N.; Hall, W.P.; Lyandres, O.; Shah, N.C.; Zhao, J.; van Duyne, R.P. Biosensing with plasmonic nanosensors. Nat. Mater. 2008, 7, 442-453.

129. Luo, X.; Morrin, A.; Killard, A.J.; Smyth, M.R. Application of nanoparticles in electrochemical sensors and biosensors. Electroanalysis 2006, 18, 319-326.

130. Wang, J.; Xu, D.; Kawde, A.-N.; Polsky, R. Metal Nanoparticle-Based Electrochemical Stripping Potentiometric Detection of DNA Hybridization. Anal. Chem. 2001, 73, 5576-5581.

131. Peng, H.; Zhang, L.; Soeller, C.; Travas-Sejdic, J. Conducting polymers for electrochemical DNA sensing. Biomaterials 2009, 30, 2132-2148. 
132. Guo, S.; Wang, E. Synthesis and electrochemical applications of gold nanoparticles. Anal. Chim. Acta 2007, 598, 181-192.

133. Rashid, M.H.; Bhattacharjee, R.R.; Kotal, A.; Mandal, T.K. Synthesis of Spongy Gold Nanocrystals with Pronounced Catalytic Activities. Langmuir 2006, 22, 7141-7143.

134. Daniel, M.-C.; Astruc, D. Gold Nanoparticles: Assembly, Supramolecular Chemistry, Quantum-Size-Related Properties, and Applications toward Biology, Catalysis, and Nanotechnology. Chem. Rev. 2003, 104, 293-346.

135. Wang, J. Electrochemical biosensing based on noble metal nanoparticles. Microchim. Acta 2012, 177, 245-270.

136. Gole, A.; Dash, C.; Ramakrishnan, V.; Sainkar, S.R.; Mandale, A.B.; Rao, M.; Sastry, M. Pepsin-Gold Colloid Conjugates: Preparation, Characterization, and Enzymatic Activity. Langmuir 2001, 17, 1674-1679.

137. Goyal, R.N.; Oyama, M.; Tyagi, A. Simultaneous determination of guanosine and guanosine-5'-triphosphate in biological sample using gold nanoparticles modified indium tin oxide electrode. Anal. Chim. Acta 2007, 581, 32-36.

138. El-Said, W.A.; Choi, J.W. Electrochemical Biosensor consisted of conducting polymer layer on gold nanodots patterned Indium Tin Oxide electrode for rapid and simultaneous determination of purine bases. Electrochim. Acta 2014, 123, 51-57.

139. Li, H.; Wang, X.; Yu, Z. Electrochemical biosensor for sensitively simultaneous determination of dopamine, uric acid, guanine, and adenine based on poly-melamine and nano Ag hybridized film-modified electrode. J. Solid State Electrochem. 2014, 18, 105-113.

140. Thangaraj, R.; Nellaiappan, S.; Sudhakaran, R.; Kumar, A.S. A flow injection analysis coupled dual electrochemical detector for selective and simultaneous detection of guanine and adenine. Electrochim. Acta 2014, 123, 485-493.

141. Pogacean, F.; Biris, A.R.; Coros, M.; Watanabe, F.; Biris, A.S.; Clichici, S.; Filip, A.; Pruneanu, S. Electrochemical oxidation of adenine using platinum electrodes modified with carbon nanotubes. Phys. E 2014, 59, 181-185.

142. Biris, A.R.; Pruneanu, S.; Pogacean, F.; Lazar, M.D.; Borodi, G.; Ardelean, S.; Dervishi, E.; Watanabe, F.; Biris, A.S. Few-layer graphene sheets with embedded gold nanoparticles for electrochemical analysis of adenine. Int. J. Nanomed. 2013, 8, 1429.

143. Niu, L.M.; Lian, K.Q.; Shi, H.M.; Wu, Y.B.; Kang, W.J.; Bi, S.Y. Characterization of an ultrasensitive biosensor based on a nano-Au/DNA/nano-Au/poly (SFR) composite and its application in the simultaneous determination of dopamine, uric acid, guanine, and adenine. Sens. Actuators B Chem. 2013, 178, 10-18.

144. Arvand, M.; Motaghed Mazhabi, R.; Niazi, A. Simultaneous determination of guanine, adenine and thymine using a modified carbon paste electrode by $\mathrm{TiO}_{2}$ nanoparticles-magnesium(II) doped natrolite zeolite. Electrochim. Acta 2013, 89, 669-679.

145. Thangaraj, R.; Kumar, A.S. Simultaneous detection of guanine and adenine in DNA and meat samples using graphitized mesoporous carbon modified electrode. J. Solid State Electrochem. 2013, 17, 583-590.

146. Toh, R.J.; Bonanni, A.; Pumera, M. Oxidation of DNA bases is influenced by their position in the DNA strand. Electrochem. Commun. 2012, 22, 207-210. 
147. Goh, M.S.; Pumera, M. Oxidation of DNA bases influenced by the presence of other bases. Electroanalysis 2012, 24, 1147-1152.

148. Goh, M.S.; Pumera, M. Number of graphene layers exhibiting an influence on oxidation of DNA bases: Analytical parameters. Anal. Chim. Acta 2012, 711, 29-31.

149. Abbaspour, A.; Noori, A. A cyclodextrin host-guest recognition approach to a label-free electrochemical DNA hybridization biosensor. Analyst 2012, 137, 1860-1865.

150. Pan, H.C.; Li, D.N.; Liu, J.T.; Li, J.P.; Zhu, W.Y.; Zhao, Y.X. Sensing thermally denatured DNA by inhibiting the growth of au nanoparticles: Spectral and electrochemical studies. J. Phys. Chem. C 2011, 115, 14461-14468.

151. Liu, T.; Zhu, X.; Cui, L.; Ju, P.; Qu, X.; Ai, S. Simultaneous determination of adenine and guanine utilizing $\mathrm{PbO}$ 2-carbon nanotubes-ionic liquid composite film modified glassy carbon electrode. J. Electroanal. Chem. 2011, 651, 216-221.

152. Goh, M.S.; Bonanni, A.; Ambrosi, A.; Sofer, Z.; Pumera, M. Chemically-modified graphenes for oxidation of DNA bases: Analytical parameters. Analyst 2011, 136, 4738-4744.

153. Goyal, R.N.; Chatterjee, S.; Rana, A.R.S.; Chasta, H. Application of modified pyrolytic graphite electrode as a sensor in the simultaneous assay of adenine and adenosine monophosphate. Sens. Actuators B Chem. 2011, 156, 198-203.

154. Cui, J.J.; Sun, D.H.; Zhou, W.J.; Liu, H.; Hu, P.G.; Ren, N.; Qin, H.M.; Huang, Z.; Lin, J.J.; Ma, H.Y. Electrocatalytic oxidation of nucleobases by TiO2 nanobelts. Phys. Chem. Chem. Phys. 2011, 13, 9232-9237.

155. Tu, X.M.; Luo, X.B.; Luo, S.L.; Yan, L.S.; Zhang, F.; Xie, Q.J. Novel carboxylation treatment and characterization of multiwalled carbon nanotubes for simultaneous sensitive determination of adenine and guanine in DNA. Microchim. Acta 2010, 169, 33-40.

156. Zheng, Y.; Yang, C.; Pu, W.; Zhang, J. Carbon nanotube-based DNA biosensor for monitoring phenolic pollutants. Microchim. Acta 2009, 166, 21-26.

157. Shen, Q.; Wang, X.M. Simultaneous determination of adenine, guanine and thymine based on beta-cyclodextrin/MWNTs modified electrode. J. Electroanal. Chem. 2009, 632, 149-153.

158. Xiao, F.; Ruan, C.; Li, J.; Liu, L.; Zhao, F.; Zeng, B. Voltammetric determination of xanthine with a single-walled carbon nanotube-ionic liquid paste modified glassy carbon electrode. Electroanalysis 2008, 20, 361-366.

159. Fang, B.; Zhang, W.; Wang, G.F.; Liu, H.Y.; Wei, S.P. Microwave-assisted preparation of a carbon nanotube/ $\mathrm{La}(\mathrm{OH})_{(3)}$ nanocomposite, and its application to electrochemical determination of adenine and guanine. Microchim. Acta 2008, 162, 175-180.

160. Umasankar, Y.; Thiagarajan, S.; Chen, S.M. Pinecone shape hydroxypropyl- $\beta$-cyclodextrin on a film of multi-walled carbon nanotubes coated with gold particles for the simultaneous determination of tyrosine, guanine, adenine and thymine. Carbon 2007, 45, 2783-2796.

161. Wang, Z.H.; Zhao, Z.J. Fabrication of nanometer electrochemical interface and the voltammetric behaviour of deoxyribonucleic acid bases. Chin. J. Anal. Chem. 2006, 34, 87-90.

162. Ye, Y.K.; Ju, H.X. Rapid detection of ssDNA and RNA using multi-walled carbon nanotubes modified screen-printed carbon electrode. Biosens. Bioelectron. 2005, 21, 735-741.

163. Wang, J.X.; Li, M.X.; Shi, Z.J.; Li, N.Q.; Gu, Z.N. Electrochemistry of DNA at single-wall carbon nanotubes. Electroanalysis 2004, 16, 140-144. 
164. Wang, J.; Li, M.; Shi, Z.; Li, N.; Gu, Z. Electrochemistry of DNA at Single-Wall Carbon Nanotubes. Electroanalysis 2004, 16, 140-144.

165. Goyal, R.N.; Singh, S.P. Voltammetric quantification of adenine and guanine at C 60 modified glassy carbon electrodes. J. Nanosci. Nanotechnol. 2006, 6, 3699-3704.

166. Lim, C.S.; Chua, C.K.; Pumera, M. Detection of biomarkers with graphene nanoplatelets and nanoribbons. Analyst 2014, 139, 1072-1080.

167. Khezrian, S.; Salimi, A.; Teymourian, H.; Hallaj, R. Label-free electrochemical IgE aptasensor based on covalent attachment of aptamer onto multiwalled carbon nanotubes/ionic liquid/chitosan nanocomposite modified electrode. Biosens. Bioelectron. 2013, 43, 218-225.

168. Chatterjee, S.; Chen, A.C. Facile electrochemical approach for the effective detection of guanine. Electrochem. Commun. 2012, 20, 29-32.

169. Yumak, T.; Kuralay, F.; Muti, M.; Sinag, A.; Erdem, A.; Abaci, S. Preparation and characterization of zinc oxide nanoparticles and their sensor applications for electrochemical monitoring of nucleic acid hybridization. Colloids Surf. B Biointerfac. 2011, 86, 397-403.

170. Hallaj, R.; Salimi, A. Nanomolar detection of guanine based on a novel cobalt oxide nanostructure-modified glassy carbon electrode. Anal. Methods 2011, 3, 911-918.

171. Balan, I.; David, I.G.; David, V.; Stoica, A.I.; Mihailciuc, C.; Stamatin, I.; Ciucu, A.A. Electrocatalytic voltammetric determination of guanine at a cobalt phthalocyanine modified carbon nanotubes paste electrode. J. Electroanal. Chem. 2011, 654, 8-12.

172. Muti, M.; Kuralay, F.; Erdem, A.; Abaci, S.; Yumak, T.; Sinag, A. Tin oxide nanoparticles-polymer modified single-use sensors for electrochemical monitoring of label-free DNA hybridization. Talanta 2010, 82, 1680-1686.

173. Zhang, X.; Jiao, K.; Liu, S.; Hu, Y. Readily reusable electrochemical DNA hybridization biosensor based on the interaction of DNA with single-walled carbon nanotubes. Anal. Chem. 2009, 81, 6006-6012.

174. Wu, D.M.; Fu, G.L.; Fang, H.Z.; Hu, L.; Li, J.L.; Yuan, X.; Zhang, Z.Y. Studies on the origin of the voltammetric response of the PC-3 cell suspension. Talanta 2009, 78, 602-607.

175. Erdem, A.; Karadeniz, H.; Caliskan, A. Single-walled carbon nanotubes modified graphite electrodes for electrochemical monitoring of nucleic acids and biomolecular interactions. Electroanalysis 2009, 21, 464-471.

176. Mazloum Ardakani, M.; Taleat, Z.; Beitollahi, H.; Salavati-Niasari, M.; Mirjalili, B.B.F.; Taghavinia, N. Electrocatalytic oxidation and nanomolar determination of guanine at the surface of a molybdenum (VI) complex- $\mathrm{TiO}_{2}$ nanoparticle modified carbon paste electrode. J. Electroanal. Chem. 2008, 624, 73-78.

177. Koehne, J.E.; Chen, H.; Cassell, A.M.; Yi, Q.; Han, J.; Meyyappan, M.; Li, J. Miniaturized multiplex label-free electronic chip for rapid nucleic acid analysis based on carbon nanotube nanoelectrode arrays. Clin. Chem. 2004, 50, 1886-1893.

178. Koehne, J.; Chen, H.; Li, J.; Cassell, A.M.; Ye, Q.; Ng, H.T.; Han, J.; Meyyappan, M. Ultrasensitive label-free DNA analysis using an electronic chip based on carbon nanotube nanoelectrode arrays. Nanotechnology 2003, 14, 1239-1245. 
179. Amiri-Aref, M.; Raoof, J.B.; Ojani, R. A highly sensitive electrochemical sensor for simultaneous voltammetric determination of noradrenaline, acetaminophen, xanthine and caffeine based on a flavonoid nanostructured modified glassy carbon electrode. Sens. Actuators B Chem. 2014, 192, 634-641.

180. Gao, Y.; Shen, C.; Di, J.; Tu, Y. Fabrication of amperometric xanthine biosensors based on direct chemistry of xanthine oxidase. Mater. Sci. Eng. C 2009, 29, 2213-2216.

181. Mu, S.; Shi, Q. Xanthine biosensor based on the direct oxidation of xanthine at an electrogenerated oligomer film. Biosens. Bioelectron. 2013, 47, 429-435.

182. Liu, H.P.; Wang, Z.H.; Zhao, X.L. Fabrication of single-wall carbon nanotube compound conducting polymer film modified electrode and simultaneous voltammetric determination of purine derivatives. Chin. J. Anal. Chem. 2011, 39, 471-475.

183. Kumar, A.S.; Shanmugam, R. Simple method for simultaneous detection of uric acid, xanthine and hypoxanthine in fish samples using a glassy carbon electrode modified with as commercially received multiwalled carbon nanotubes. Anal. Methods 2011, 3, 2088-2094.

184. Raj, M.A.; John, S.A. Simultaneous determination of uric acid, xanthine, hypoxanthine and caffeine in human blood serum and urine samples using electrochemically reduced graphene oxide modified electrode. Anal. Chim. Acta 2013, 771, 14-20.

185. Zhang, F.; Wang, Z.; Zhang, Y.; Zheng, Z.; Wang, C.; Du, Y.; Ye, W. Simultaneous electrochemical determination of uric acid, xanthine and hypoxanthine based on poly(l-arginine)/graphene composite film modified electrode. Talanta 2012, 93, 320-325.

186. Xiao, F.; Zhao, F.; Li, J.; Liu, L.; Zeng, B. Characterization of hydrophobic ionic liquid-carbon nanotubes-gold nanoparticles composite film coated electrode and the simultaneous voltammetric determination of guanine and adenine. Electrochim. Acta 2008, 53, 7781-7788.

187. Love, J.C.; Estroff, L.A.; Kriebel, J.K.; Nuzzo, R.G.; Whitesides, G.M. Self-assembled monolayers of thiolates on metals as a form of nanotechnology. Chem. Rev. 2005, 105, 1103-1170.

188. Vahlberg, C.; Linares, M.; Villaume, S.; Norman, P.; Uvdal, K. Noradrenaline and a thiol analogue on gold surfaces: An infrared reflection-absorption spectroscopy, X-ray photoelectron spectroscopy, and near-edge X-ray absorption fine structure spectroscopy study. J. Phys. Chem. C 2011, 115, 165-175.

189. Cossaro, A.; Mazzarello, R.; Rousseau, R.; Casalis, L.; Verdini, A.; Kohlmeyer, A.; Floreano, L.; Scandolo, S.; Morgante, A.; Klein, M.L.; et al. X-ray diffraction and computation yield the structure of alkanethiols on gold(111). Science 2008, 321, 943-946.

190. Sowerby, S.J.; Edelwirth, M.; Heckl, W.M. Self-assembly at the prebiotic solid-liquid interface: Structures of self-assembled monolayers of adenine and guanine bases formed on inorganic surfaces. J. Phys. Chem. B 1998, 102, 5914-5922.

191. John Jeevagan, A.; John, S.A. Electrochemical sensor for guanine using a self-assembled monolayer of 1,8,15,22-tetraaminophthalocyanatonickel(II) on glassy carbon electrode. Anal. Biochem. 2012, $424,21-26$.

192. Dracka, O. Theory of current elimination in linear voltammetry. J. Electroanal. Chem. 1996, $402,18-28$. 
193. Trnkova, L. Application of elimination voltammetry with linear scan in biochemistry. In Utilizing of Bio-Electrochemical and Mathematical Methods in Biological Research, Adam, V., Kizek, R., Eds.; Research Signpost: Kerala, India, 2007; Volume 4, pp. 51-74.

194. Trnkova, L.; Dracka, O. Elimination voltammetry. Experimental verification and extension of theoretical results. J. Electroanal. Chem. 1996, 413, 123-129.

195. Trnkova, L.; Kizek, R.; Dracka, O. Application of elimination voltammetry to adsorptive stripping of DNA. Electroanalysis 2000, 12, 905-911.

196. Trnkova, L. Identification of current nature by elimination voltammetry with linear scan. J. Electroanal. Chem. 2005, 582, 258-266.

197. Trnkova, L.; Zerzankova, L.; Dycka, F.; Mikelova, R.; Jelen, F. Study of copper and purine-copper complexes on modified carbon electrodes by cyclic and elimination voltammetry. Sensors 2008, 8, 429-444.

198. Aladag, N.; Trnkova, L.; Kourilova, A.; Ozsoz, M.; Jelen, F. Voltammetric Study of Aminopurines on Pencil Graphite Electrode in the Presence of Copper Ions. Electroanalysis 2010, 22, 1675-1681.

199. Navratil, R.; Jelen, F.; Kayran, U.Y.; Trnkova, L. A pencil graphite electrode in situ modified by monovalent copper: A promising tool for the determination of methylxanthines. Electroanalysis 2014, 26, 952-961.

200. Serrano, N.; Alberich, A.; Trnkova, L. Oxidation of 6-Benzylaminopurine-Copper(I) Complex on Pencil Graphite Electrode. Electroanalysis 2012, 24, 955-960.

201. Klosova, K.; Serrano, N.; Salyk, O.; Trnkova, L. Template-assisted fabrication and characterization of nanostructured copper electrode for adenine detection. Curr. Nanosci. 2011, 7, 984-994.

(C) 2015 by the authors; licensee MDPI, Basel, Switzerland. This article is an open access article distributed under the terms and conditions of the Creative Commons Attribution license (http://creativecommons.org/licenses/by/4.0/). 